\title{
TWO DECADES OF ENVIRONMENTAL ISOTOPE RECORDS IN CROATIA: RECONSTRUCTION OF THE PAST AND PREDICTION OF FUTURE LEVELS
}

\author{
INES KRAJCAR-BRONIĆ, NADA HORVATINČIĆ and BOGOMIL OBELIĆ
}

\author{
Ruđer Boß̌ković Institute, P.O. Box 1016, 10001 Zagreb, Croatia
}

\begin{abstract}
A two-decade-long record of environmental isotopes $\left({ }^{2} \mathrm{H},{ }^{3} \mathrm{H},{ }^{14} \mathrm{C},{ }^{18} \mathrm{O}\right)$ in Croatia is presented and the data are statistically analyzed. The atmospheric ${ }^{14} \mathrm{C}$ activity for the period before the actual measurements started is reconstructed by measuring tree rings from the clean-air sites, and the past tritium activity in precipitation is estimated by the correlation of our data with the Vienna station record. The long-term ${ }^{3} \mathrm{H}$ record helped to determine a locally contaminated sampling site, and new clean sites are put into operation. The ${ }^{14} \mathrm{C}$ data were fitted by an analytical function and the prediction of future levels is given assuming that the rate of the ${ }^{14} \mathrm{C}$ releases remains constant. From the long-term stable isotope data record, the local meteoric water line and the temperature gradient of $\delta^{18} \mathrm{O}$ in precipitation are determined.
\end{abstract}

\section{INTRODUCTION}

Monitoring of environmental levels of radioactive $\left({ }^{14} \mathrm{C},{ }^{3} \mathrm{H}\right)$ and stable isotopes $\left({ }^{2} \mathrm{H},{ }^{13} \mathrm{C},{ }^{18} \mathrm{O}\right)$ in the atmosphere and biosphere started about four decades ago, approximately at the same time as the significant anthropogenic disturbance of natural distributions of radiocarbon and tritium occurred. In the Radiocarbon and Tritium Laboratory of the Ruđer Boškovic Institute in Zagreb (Croatia) measurements of atmospheric ${ }^{3} \mathrm{H}$ and ${ }^{14} \mathrm{C}$ have been performed since 1976 and 1978, respectively. A few years later, the lab also started monitoring stable isotopes $\left({ }^{2} \mathrm{H}\right.$ and $\left.{ }^{18} \mathrm{O}\right)$ in precipitation samples in cooperation with the Jožef Stefan Institute in Ljubljana, Slovenia. These two stations have been continuously active since then, as shown in Table 1.

The disturbances of natural distributions of ${ }^{3} \mathrm{H}$ and ${ }^{14} \mathrm{C}$ made these isotopes very important tracers in, e.g., environmental, climatological and hydrological studies. A global network for ${ }^{2} \mathrm{H},{ }^{3} \mathrm{H}$ and ${ }^{18} \mathrm{O}$ isotopes in monthly precipitation was organized by the International Atomic Energy Agency (IAEA) and the World Meteorological Organization (WMO). The results have been regularly published by the IAEA $(1969,1970,1971,1973,1975,1979,1983,1986,1990,1994)$. The data from ca. 200 stations from around the world consist of tritium concentration and stable isotope $\left({ }^{2} \mathrm{H},{ }^{18} \mathrm{O}\right)$ content of monthly precipitation samples, and also relevant meteorological data: amount and type of precipitation, mean monthly surface air temperature and humidity. All available data from the network were recently analyzed by Rozanski et al. $(1991,1993)$. Several representative stations with different climatic conditions demonstrated temporal and spatial variations of isotope distributions. The importance of long-term stable isotope records for climatic studies is pointed out (Rożanski $e t$ al. 1993), as well as the importance of ${ }^{3} \mathrm{H}$ monitoring because of the increasing input from anthropogenic sources (Rożanski et al. 1991).

The ${ }^{3} \mathrm{H}$ and stable isotope data measured at the Zagreb and Ljubljana stations have been regularly published since 1976 and 1981, respectively (IAEA 1983, 1986, 1990, 1994). In addition to these two sites, several other sampling sites have been included in the monitoring, as shown in Table 1. All the sampling stations, except Rijeka (Fig. 1) have a continental climate. The nearest continental station of the IAEA network is Vienna-Hohe Varte, and our results are compared mostly with data from that station. The Rijeka station has a Mediterranean climate, and the ${ }^{3} \mathrm{H}$ activity in Rijeka precipitation is compared to that in Genoa (Italy), which is the closest Mediterranean station.

Natural distribution of atmospheric ${ }^{14} \mathrm{C}$ was disturbed during the early 1960 s due to the release of bomb-produced ${ }^{14} \mathrm{C}$ into the atmosphere. The new global distribution can be further locally affected by various nuclear facilities (nuclear power plants (NPPs), medical and research institutions that use 
labeled material) or by intensive combustion of fossil fuels in metropolitan or industrial areas. While the first type of ${ }^{14} \mathrm{C}$ sources tends to increase the local ${ }^{14} \mathrm{C}$ activity, the latter source (fossil fuel contribution) tends to decrease the local ${ }^{14} \mathrm{C}$ activity (the Suess effect) and is therefore considered as a "sink" of atmospheric ${ }^{14} \mathrm{C}$.

TABLE 1. Sampling sites for environmental samples: geographical position, monitored isotopes, and the period when the sites have been active. Sampling site identification symbols are given in brackets and are as in Figure 1.

\begin{tabular}{|c|c|c|c|c|}
\hline $\begin{array}{l}\text { Location and } \\
\text { site name }\end{array}$ & Coordinates & $\begin{array}{c}\text { Altitude } \\
\text { (m asl) }\end{array}$ & Isotopes & $\begin{array}{l}\text { Active sampling } \\
\text { period }\end{array}$ \\
\hline Zagreb-RBI* (R) & $\begin{array}{l}45^{\circ} 49^{\prime} \mathrm{N} \\
15^{\circ} 58^{\prime} \mathrm{E}\end{array}$ & 165 & ${ }^{2} \mathrm{H},{ }^{3} \mathrm{H},{ }^{18} \mathrm{O},{ }^{14} \mathrm{C}$ & Since 1976 \\
\hline Zagreb-Gric (G) & $\begin{array}{l}45^{\circ} 48^{\prime} \mathrm{N} \\
15^{\circ} 57^{\prime} \mathrm{E}\end{array}$ & 158 & ${ }^{2} \mathrm{H},{ }^{3} \mathrm{H},{ }^{18} \mathrm{O}$ & Since 1996 \\
\hline $\begin{array}{l}\text { Puntijarka (Pn) } \\
\text { Mt. Medvednica }\end{array}$ & $\begin{array}{l}45^{\circ} 55^{\prime} \mathrm{N} \\
15^{\circ} 57^{\prime} \mathrm{E}\end{array}$ & 988 & ${ }^{2} \mathrm{H},{ }^{3} \mathrm{H},{ }^{18} \mathrm{O},{ }^{14} \mathrm{C}$ & Since 1995 \\
\hline Plitvice (3) & $\begin{array}{l}44^{\circ} 50^{\prime} \mathrm{N} \\
15^{\circ} 35^{\prime} \mathrm{E}\end{array}$ & 536 & ${ }^{3} \mathrm{H},{ }^{14} \mathrm{C}$ & $1976-1990$ \\
\hline Rijeka (4) & $\begin{array}{l}45^{\circ} 20^{\prime} \mathrm{N} \\
14^{\circ} 30^{\prime} \mathrm{E}\end{array}$ & $\sim 20$ & ${ }^{3} \mathrm{H}$ & 1986-1987 \\
\hline Ljubljana (2) & $\begin{array}{l}46^{\circ} 04^{\prime} \mathrm{N} \\
14^{\circ} 31^{\prime} \mathrm{E}\end{array}$ & 299 & ${ }^{2} \mathrm{H},{ }^{3} \mathrm{H},{ }^{18} \mathrm{O}$ & Since 1981 \\
\hline $\begin{array}{l}\text { Libna (L) } \\
1.5 \mathrm{~km} \text { from NPPK* }\end{array}$ & $\begin{array}{l}45^{\circ} 55^{\prime} \mathrm{N} \\
15^{\circ} 31^{\prime} \mathrm{E}\end{array}$ & $\sim 180$ & ${ }^{14} \mathrm{C}$ & 1984-1986 \\
\hline $\begin{array}{l}\text { Dobova (D) } \\
12 \mathrm{~km} \text { E from NPPK }\end{array}$ & $\begin{array}{l}45^{\circ} 50^{\prime} \mathrm{N} \\
15^{\circ} 40^{\prime} \mathrm{E}\end{array}$ & $\sim 170$ & ${ }^{14} \mathrm{C}$ & $1984-1986$ \\
\hline $\begin{array}{l}\text { Pesje (P) } \\
3 \mathrm{~km} \text { E from NPPK }\end{array}$ & $\begin{array}{l}45^{\circ} 54^{\prime} \mathrm{N} \\
15^{\circ} 35^{\prime} \mathrm{E}\end{array}$ & $\sim 160$ & ${ }^{14} \mathrm{C}$ & 1984-1986 \\
\hline $\begin{array}{l}\text { Bistra (B) } \\
34 \mathrm{~km} \text { E from NPPK }\end{array}$ & $\begin{array}{l}45^{\circ} 54^{\prime} \mathrm{N} \\
15^{\circ} 50^{\prime} \mathrm{E} \\
\end{array}$ & $\sim 200$ & ${ }^{14} \mathrm{C}$ & 1984-1986 \\
\hline
\end{tabular}

*RBI=Ruđer Boškovic Institute; NPPK= Krško NPP

For atmospheric ${ }^{14} \mathrm{C}$, no such large global network, such as that for isotopes in precipitation has been established. Several stations in Germany (Levin et al. 1980, 1992, 1995; Levin and Kromer 1997; Segl et al. 1983), Canada (McNeely 1994), Norway and the Netherlands (Meijer et al. 1994) have long records of ${ }^{14} \mathrm{CO}_{2}$ activity. The University of Heidelberg organized a network of seven stations distributed world-wide between $82^{\circ} \mathrm{N}$ and $71^{\circ} \mathrm{S}$ (Levin et al. 1992, Levin and Kromer 1997) for monitoring of atmospheric $\mathrm{CO}_{2}$ in the troposphere. In addition, isotopic composition of carbon in atmospheric $\mathrm{CO}_{2}$ has been measured for more than a decade in Krakow, Poland (Kuc and Zimnoch 1998) and in Sweden (Olsson 1989).

Partial presentation of our data can be found in previous papers (Horvatinčić et al. 1986, 1992, 1996a, 1996b; Krajcar Bronić et al. 1986, 1992; Obelić et al. 1986, 1987, 1992; Kozák et al. 1989). We present here the complete isotope data record $\left({ }^{2} \mathrm{H},{ }^{3} \mathrm{H},{ }^{14} \mathrm{C},{ }^{18} \mathrm{O}\right)$ of atmospheric samples measured during the last two decades in our laboratory. Our statistical analysis of the stable isotope and 
${ }^{3} \mathrm{H}$ data in precipitation is compared with the analysis of Rozanski et al. $(1991,1993) .{ }^{14} \mathrm{C}$ activity of atmospheric $\mathrm{CO}_{2}$ is compared with other atmospheric measurements (Levin et al. 1995; Levin and Kromer 1997; McNeely 1994; Meijer et al. 1994).

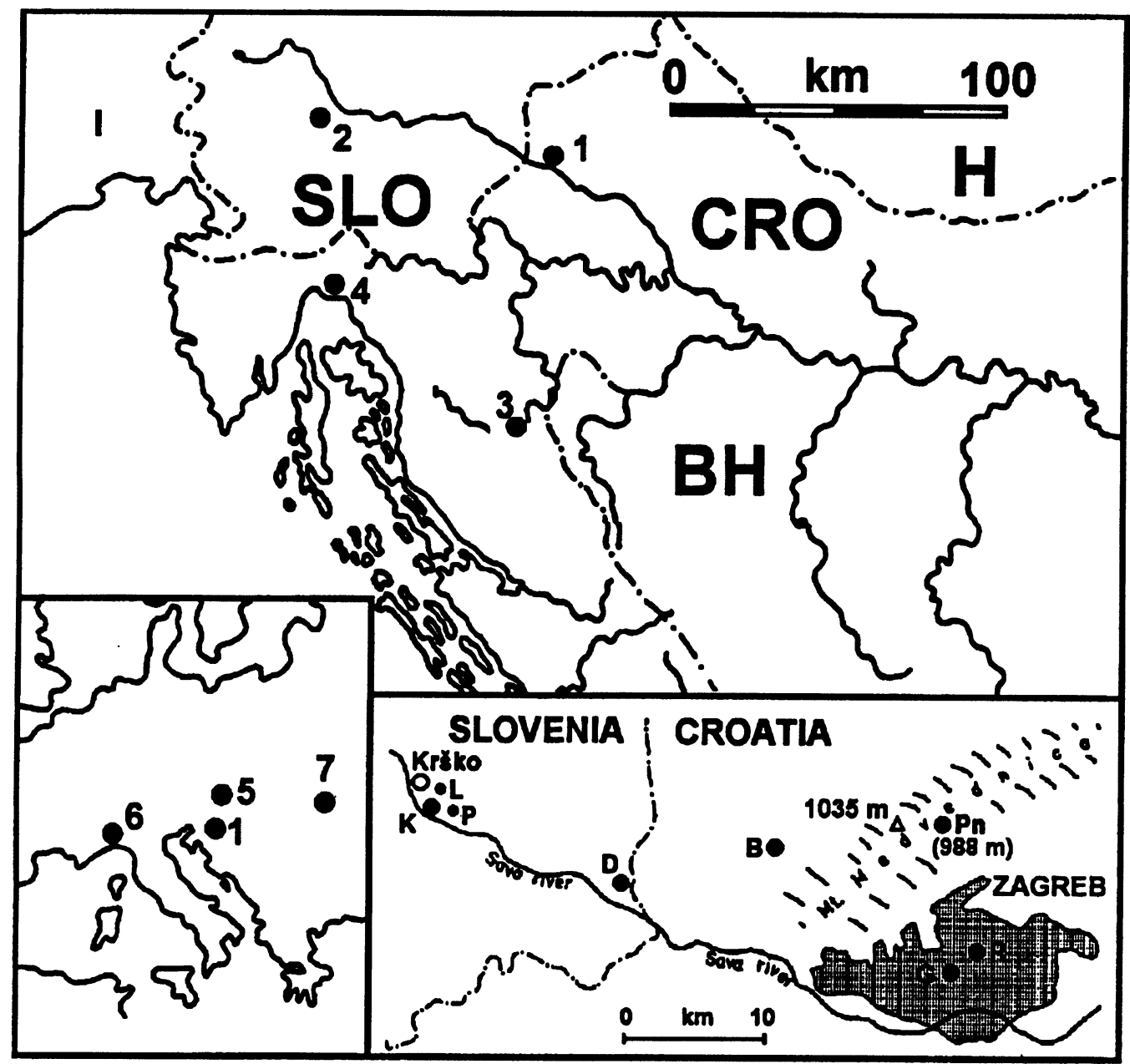

Fig. 1. Sites for environmental samples in Croatia and Slovenia. 1. Zagreb; 2. Ljubljana; 3. Plitvice; 4. Rijeka. Lower left corner: the European stations, near our sampling sites. 5. Vienna (Austria); 6. Genoa (Italy); 7. Mt. Matra (Hungary). Lower right corner: locations in the city of Zagreb, at Mt. Medvednica, and around the Krško NPP. K=NPPK; L= Libna; P=Pesje; $\mathrm{D}=$ Dobova; $\mathrm{B}=\mathrm{Bistra}$; $\mathrm{Pn}=$ Puntijarka, $\mathrm{G}=\mathrm{Z}$ agreb-Gric; $R=Z$ Zagreb-RBI.

\section{Sample Preparation and Measurement Methods}

Experimental methods of sample collection, preparation and measurement used in our laboratory have been previously discussed in detail (Horvatinčic 1980; Horvatincic et al. 1986, 1989, 1990; Obelic et al. 1986). We describe here only the most important details.

Organic samples for ${ }^{14} \mathrm{C}$ activity measurement are chemically pretreated by the $\mathrm{HCl}-\mathrm{NaOH}-\mathrm{HCl}$ (or A-B-A) method (Srdoc et al. 1971; Krajcar Bronic et al. 1995) and then combusted in a stream of purified oxygen. The preparation of cellulose from separated tree rings has been described in detail 
by Obelic et al. (1992), Kozák and Rank (1981) and Kozák et al. (1989). Samples of atmospheric $\mathrm{CO}_{2}$ are collected by exposing $c a .100 \mathrm{~mL}$ of saturated carbonate-free sodium hydroxide solution in a tray protected by a wire-mesh to the open atmosphere. The exposure time is typically one month. The absorbed $\mathrm{CO}_{2}$ is released in the laboratory by dissolving the sodium carbonate in diluted $\mathrm{HCl}$. The $\mathrm{CO}_{2}$ obtained either by combustion of organic samples or by dissolution of carbonates by $\mathrm{HCl}$ is then catalytically converted to $\mathrm{CH}_{4}$ by hydrogenation over a Ru catalyst. Purified methane is used as a filling gas in a proportional counter for ${ }^{14} \mathrm{C}$ activity measurement. For ${ }^{3} \mathrm{H}$ measurements, a wallless proportional counter filled with methane is used. Water samples are converted to methane by reaction with aluminum carbide at $150^{\circ} \mathrm{C}$ (Horvatinčic 1980).

Air moisture (atmospheric water vapor) has been sampled regularly since 1988, although some occasional samplings were done before that time. All the samples of atmospheric moisture at the Institute and in the various places in the city are collected by absorption of air moisture on silicagel in a flow mode (Horvatinčic et al. 1989; Bistrović et al. 1994). Evaporation and isotope-exchange with ${ }^{3} \mathrm{H}$-free water is used for regular checks of laboratory air, while the method of freezing out of the water vapor on Al plates cooled with liquid nitrogen is used for fast (immediate) sampling when necessary. Comparison of different sampling methods gives satisfactory agreement, taking into account different time periods needed for the sample collection.

Stable isotopes ${ }^{18} \mathrm{O}$ and ${ }^{2} \mathrm{H}$ in water samples are measured by the mass spectrometer MAT 250 at the Jožef Stefan Institute in Ljubljana (Slovenia). Water samples for $\delta^{2} \mathrm{H}$ determination are reduced to $\mathrm{H}_{2}$ by passing over hot $\mathrm{Zn}$, whereas for ${ }^{18} \mathrm{O}$ measurement, water samples are equilibrated with $\mathrm{CO}_{2}$ gas of known isotopic composition.

Our laboratory participated in several intercomparison studies for both ${ }^{14} \mathrm{C}$ and ${ }^{3} \mathrm{H}$ isotopes (Scott $e t$ al. 1990, 1992; Rozanski et al. 1992). The results of ${ }^{14} \mathrm{C}$ intercomparisons have been discussed in Horvatinčić et al. (1990) and Krajcar Bronic et al. (1995). The agreement between our results and the median values reported for each intercomparison sample was very good. Intercomparison of ${ }^{3} \mathrm{H}$ activities in water samples, organized by the IAEA in 1986 and 1994, also showed good agreement between our results and the median values (Hut 1986).

The results of isotope content are reported throughout the paper in the following units.

- ${ }^{14} \mathrm{C}$ as $\Delta{ }^{14} \mathrm{C}$ (in \%o) deviation from the standard sample, 95\% activity of the NBS Oxalic acid (I) (Stuiver and Polach 1977),

- ${ }^{3} \mathrm{H}$ activity in $\mathrm{Bq} \mathrm{L}^{-1}$, which is related to the commonly used $\mathrm{TU}\left({ }^{3} \mathrm{H}\right.$ unit) as $1 \mathrm{TU}=0.118$ $\mathrm{Bq} \mathrm{L}{ }^{-1}$,

- Stable isotope content is expressed in $\delta$-notation, as relative deviation from the isotope content of the standard SMOW (standard mean ocean water) sample.

\section{RESULTS}

\section{Radiocarbon}

Our monitoring of ${ }^{14} \mathrm{C}$ includes three different types of sites (Table 1, Fig. 1):

1. Sites far from large cities and nuclear power facilities, which are supposed to reflect only the global disturbance of the atmospheric ${ }^{14} \mathrm{C}$ activity-the so-called "clean-air" sites (Plitvice, Puntijarka). After 1990, the "clean-air" site at Plitvice was not reachable, hence we started our monitoring at the Puntijarka station, on Mt. Medvednica near Zagreb. The station is $15 \mathrm{~km}$ from 
the city of Zagreb and $988 \mathrm{~m}$ above sea level (asl), and prevailing winds blow from Puntijarka to Zagreb.

2. A densely populated industrial center (Zagreb), where the Suess effect may be expected. However, there are also large research and medical institutions that use radioactive-labeled material, and some local contamination may be observed.

3. Several locations around the Krško NPP, which is situated $37 \mathrm{~km}$ northwest of Zagreb in the Republic of Slovenia. Libna is the closest monitoring station, only $1.5 \mathrm{~km}$ from the plant smokestack. Other sampling sites (Pesje, Dobova, Bistra) were chosen according to their geography and the prevailing weather conditions.

We monitored ${ }^{14} \mathrm{C}$ in the biosphere through atmospheric $\mathrm{CO}_{2}$, or by annual or short-lived plants (seasonal fruits or vegetable, grass) and leaves. All these materials closely monitor the atmospheric ${ }^{14} \mathrm{C}$ concentration (Levin et al. 1980; Otlet et al. 1992). We collected organic material and atmospheric $\mathrm{CO}_{2}$ at "clean-air" sites Plitvice and Puntijarka (Table 1, Fig. 1), and at various sites in the vicinity of the Krško NPP, while in the vicinity of Zagreb, only atmospheric $\mathrm{CO}_{2}$ samples were collected. We also measured ${ }^{14} \mathrm{C}$ activity in tree rings from "clean-air" sites Plitvice and Matra, and from the vicinity of the NPP. The results obtained around the Krško NPP were discussed extensively by Obelic et al. $(1986,1987)$.

In Figure 2, we present the measured ${ }^{14} \mathrm{C}$ activity in short-lived plants collected at the Plitvice site and in atmospheric $\mathrm{CO}_{2}$ at the Zagreb-RBI site for the period 1979-1996. For comparison, we also show ${ }^{14} \mathrm{C}$ activity in rings (1979-1983) of a linden tree that was felled at the Libna station. A continuous decrease in the ${ }^{14} \mathrm{C}$ activity at all three sites is evident. Segl et al. (1983) determined for the period 1976-1982 an average decrease in $\Delta^{14} \mathrm{C}$ of $20 \%$ per year for "clean-air" continental stations.

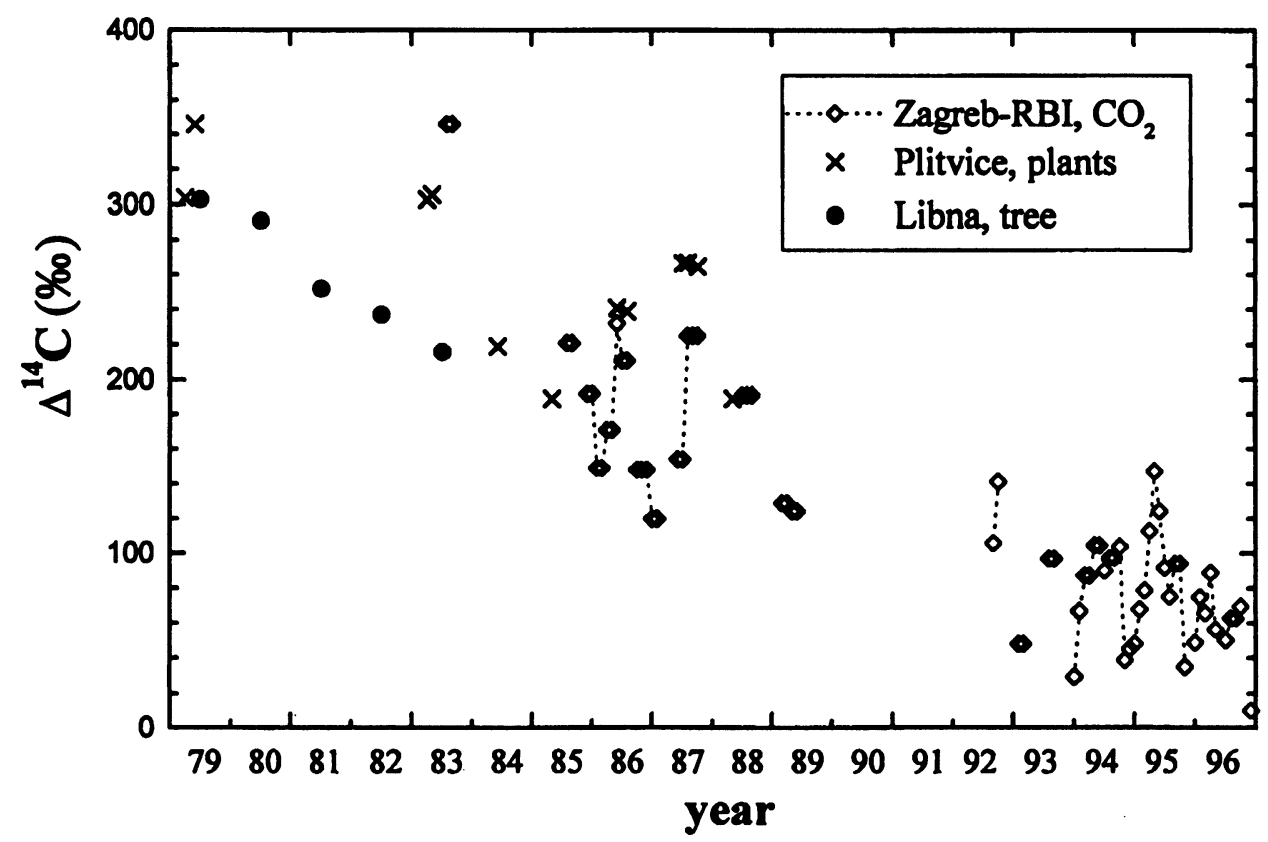

Fig. 2. $\Delta^{14} \mathrm{C}$ values in monthly samples of atmospheric $\mathrm{CO}_{2}$ collected at Zagreb-RBI and in some short-lived plants collected at the Plitvice site $1979-1996 .{ }^{14} \mathrm{C}$ activities taken from rings from the linden tree (Libna station) are also shown. The broken line connecting subsequent data points (Zagreb-RBI, $\mathrm{CO}_{2}$ ) indicates seasonal changes in $\Delta^{14} \mathrm{C}$. 
The decrease of $\sim 22 \% 0$ per year is obtained for the period 1979-1983 from our tree-ring data (Fig. 2). However, in recent years, the yearly decrease in $\Delta^{14} \mathrm{C}$ is lower: for the period $1984-1996$ the $\Delta{ }^{14} \mathrm{C}$ data measured at the Zagreb-RBI station show a decrease of $12 \%$ per year, and the data measured at Plitvice in the period 1979-1990 a decrease of 10.6\%o per year. Similarly, Levin et al. (1992) report a decrease of $14.1 \% 0$ and 9.7\%o per year for the periods 1983-1985 and 1985-1989, respectively, at the Schauinsland station.

As Figure 2 shows, seasonal fluctuations in atmospheric $\Delta^{14} \mathrm{C}$ are superposed to the mean yearly values: the highest ${ }^{14} \mathrm{C}$ activity is measured during summer, and the lowest in winter (see also Fig. 3 ). The analysis of the deviations of the monthly values from the mean yearly $\Delta^{14} \mathrm{C}$ for four full-year cycles $(1986,1994-1996)$ shows that the averaged maximal deviations are observed in May (41\%o above the mean $\Delta^{14} \mathrm{C}$ ) and in December (40\%o below the mean yearly $\Delta^{14} \mathrm{C}$ ), giving average yearly peak-to-peak variations of $81 \%$. Seasonal peak-to-peak variations at the "clean-air" site Shauinsland were determined to be $40 \%$ (Segl et al. 1983), while the seasonal peak-to-peak variations at the Krakow site, which is influenced by the fossil-fuel carbon, were 56\%o (Kuc and Zimnoch 1998). Thus, higher variation in Zagreb indicate greater influence of the fossil-fuel carbon (i.e., the stronger Suess effect) during the winter months. In Figure 3, we compare $\Delta^{14} \mathrm{C}$ values measured in the city of Zagreb (Zagreb-RBI site) with those measured at the clean-air site Puntijarka during 1995 and 1996. In the colder time of the year, the $\Delta^{14} \mathrm{C}$ values in the city of Zagreb are much lower than at Puntijarka, confirming the conclusion derived from the comparison with the Schauinsland data. The mean yearly $\Delta^{14} \mathrm{C}$ values in Zagreb (81\%o, 88\%o and 56\%o for 1994, 1995 and 1996, respectively) are lower than those measured at Schauinsland (117\%o, 111\%o and 102\%o, respectively; Levin and Kromer 1997) or in Kraków (120-125\%o; Kuc and Zimnoch 1998) for the same period. Even the mean $\Delta^{14} \mathrm{C}$ at Puntijarka (82.4\%o for 1996) is lower than the above-mentioned values, although this site does not seem to be influenced by fossil-fuel carbon.

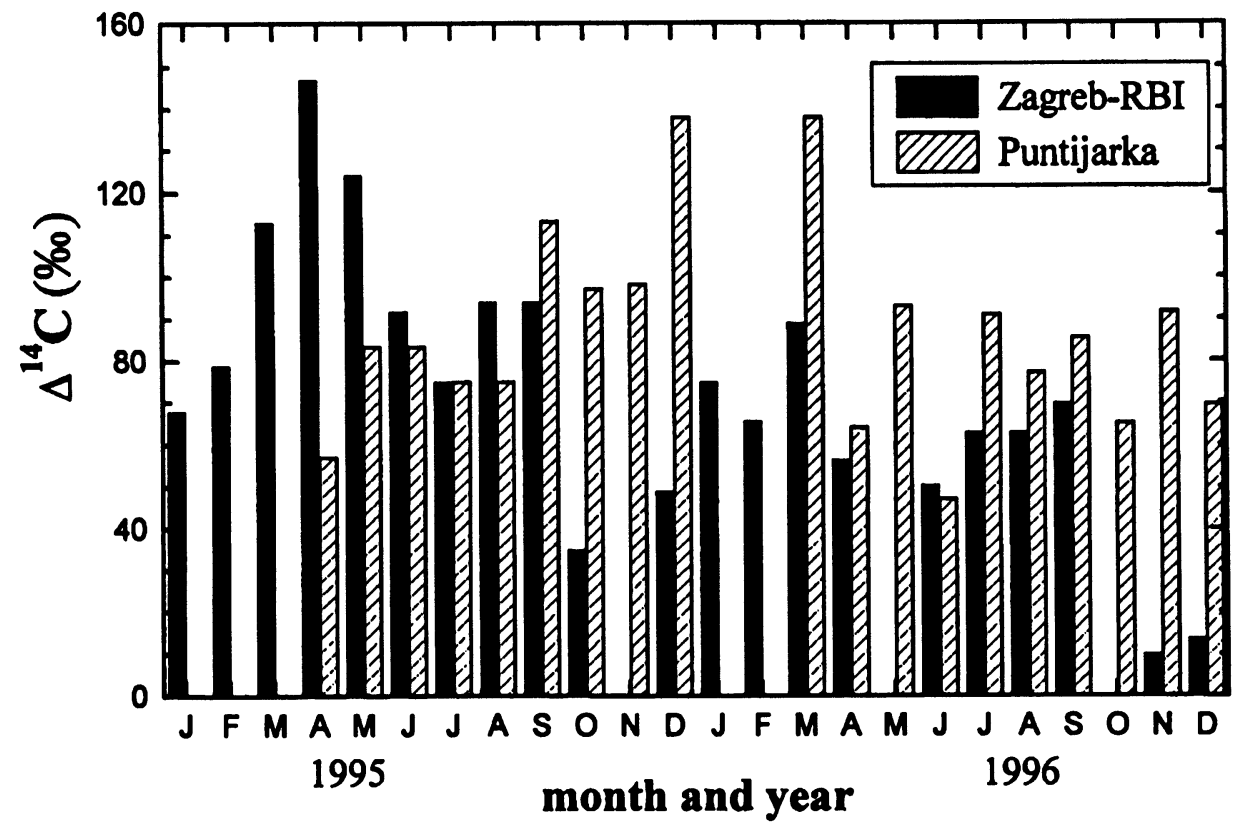

Fig. 3. Comparison of the $\Delta^{14} \mathrm{C}$ values in the city of Zagreb and at the clean-air station Puntijarka for 1995-1996 
A detailed inspection of the atmospheric ${ }^{14} \mathrm{C}$ activity around the Krško NPP results in slight differences among various sampling sites. The average $\Delta^{14} \mathrm{C}$ values in atmospheric $\mathrm{CO}_{2}$ measured for the period 1984-1986 at stations Zagreb, Dobova and Bistra (Fig. 1) were (208 \pm 12$) \% o,(207 \pm 11) \% 0$ and $(216 \pm 9) \% o$, respectively. The differences between these sites are not significant, according to the given uncertainties. Only the samples from Libna station, closest to the Krsko NPP, gave somewhat higher mean $\Delta^{14} \mathrm{C}$ values, $(230 \pm 19) \%$ for 1984 and $(216 \pm 20) \%$ for 1985 , than those taken at the above-mentioned locations. The highest increase was observed in July $1984\left(\Delta^{14} \mathrm{C}=270 \%\right)$ and coincided with the yearly exchange of one-third of the fuel elements in the reactor core. For 1984 a mean ${ }^{14} \mathrm{C}$ excess of $22 \% 0$ above the "clean air" level was measured at the Libna station (Obelic et al. 1986).

The ${ }^{14} \mathrm{C}$ activity of tree rings from Plitvice and Mt. Matra, Hungary, is used to reconstruct the atmospheric ${ }^{14} \mathrm{C}$ activity for the period $1950-1986$. The results are presented in Figure 4 and are compared with the long-term measurements of atmospheric $\mathrm{CO}_{2}$ (from Germany, Canada, the Netherlands), as well as with the mean $\Delta^{14} \mathrm{C}$ values for atmospheric $\mathrm{CO}_{2}$ at the Zagreb-RBI station. The two sets of $\Delta^{14} \mathrm{C}$ values in tree rings agree well with the mean yearly $\Delta^{14} \mathrm{C}$ for atmospheric $\mathrm{CO}_{2}$ at the Schauinsland station. All the curves follow each other very well; all give a maximal ${ }^{14} \mathrm{C}$ atmospheric activity in 1963-1964 of 900\%o, and show a discontinuity in decrease in 1971-1972. However, $\Delta^{14} \mathrm{C}$ values in Canada (McNeely 1994) are systematically higher, and the Groningen data (Meijer et al. 1994) are systematically lower than the clean-air site Schauinsland (Levin and Kromer 1997). Our data at Zagreb-RBI agree well with the Groningen data, and are thus lower than the Schauinsland data.

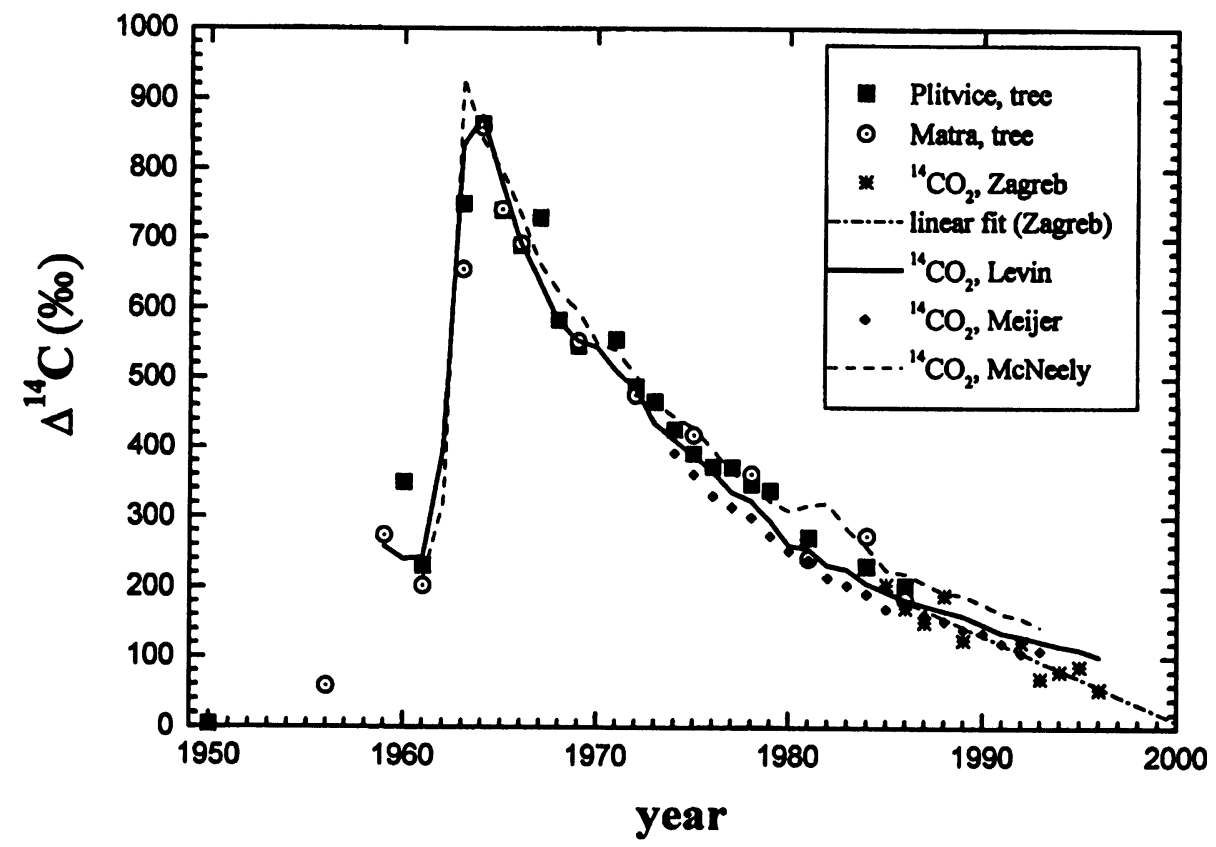

Fig. 4. $\Delta^{14} \mathrm{C}$ in tree rings from Plitvice, Mt. Matra, and the mean yearly $\Delta^{14} \mathrm{C}$ values in the Zagreb-RBI $\mathrm{CO}_{2}$ samples. Our data are compared with atmospheric ${ }^{14} \mathrm{C}$ activities at Schauinsland (Levin et al. 1995; Levin and Kromer 1997), Groningen (Meijer et al. 1994) and Canada (McNeely 1994). The dashed-dotted line represents linear fitting to the Zagreb-RBI data, and is extrapolated to the year 2000.

We fitted an exponential decay function to the Plitvice tree-ring data for 1964-1986, to the Matra treering data (1964-1986), and to the atmospheric $\mathrm{CO}_{2}$ data by Levin et al. (for 1964-1996) and by 
McNeely (for 1963-1993). (The data for Meijer et al. (1994) could not be fitted with the same function). All the fits gave a time constant for the decay of $\sim 16$ yr. Extrapolation to the year 2000 resulted in values of $\sim 120 \%$, except the Schauinsland data (Levin and Kromer 1997), which resulted in predicted $\Delta^{14} \mathrm{C}$ of $90 \%$. However, recent mean atmospheric ${ }^{14} \mathrm{C}$ activity measured in the Zagreb area is already lower than these values. As Figure 4 shows, the exponential decay curve may be divided to several time periods, and each of the period may be approximated by a linear function: 1) a sudden increase in atmospheric ${ }^{14} \mathrm{C}$ activity for the period $~ 1955-1964 ; 2$ ) for $1964-1969$, a period of fast decrease in $\Delta^{14} \mathrm{C}$ at $\sim 50-65 \%$ per year; 3 ) for $1970-1980$, a lower decrease rate of $\sim 20-30 \%$ per year; and 4) for 1980-present, a decay rate of $12 \%$ per year. Data from recent years (starting from 1982 to the most recent) are thus fitted to a linear function. The Zagreb-RBI mean yearly ${ }^{14} \mathrm{C}$ activities gave a decrease of 12.2\%o per year, data of Meijer et al. (1994), 9.8\%o per year, and Levin and Kromer (1997), $\sim 9 \%$ per year. By using the obtained linear regressions, the $\Delta^{14} \mathrm{C}$ values can be extrapolated to future years. Our data (Zagreb-RBI) predict that due to local contamination (fossil fuel $\mathrm{CO}_{2}$ ), a mean $\Delta^{14} \mathrm{C}$ of $0 \%$ might be reached by the year 2000 . The Groningen data (Meijer et al. 1994) and the Schauinsland data (Levin and Kromer 1997) predict for the same year slightly higher values of $\sim 35 \%$ and $\sim 62 \%$, respectively, and the $\Delta^{14} \mathrm{C}$ value equal to $0 \%$ for the years 2004 and 2007 , respectively.

\section{Tritium}

Figure 5 shows the complete record of ${ }^{3} \mathrm{H}$ activity of the monthly precipitation of Zagreb and Ljubljana. The long-term record enabled us to recognize some local contamination in Ljubljana during 1985 and early 1986 (not shown in Fig. 5). By the end of 1993, the first sign of possible local contamination at the site Zagreb-RBI was observed. A rain gauge has been situated at the Ruđer Bošković Institute since the beginning of the monitoring in 1976, and at the same location ${ }^{3} \mathrm{H}$ in atmospheric

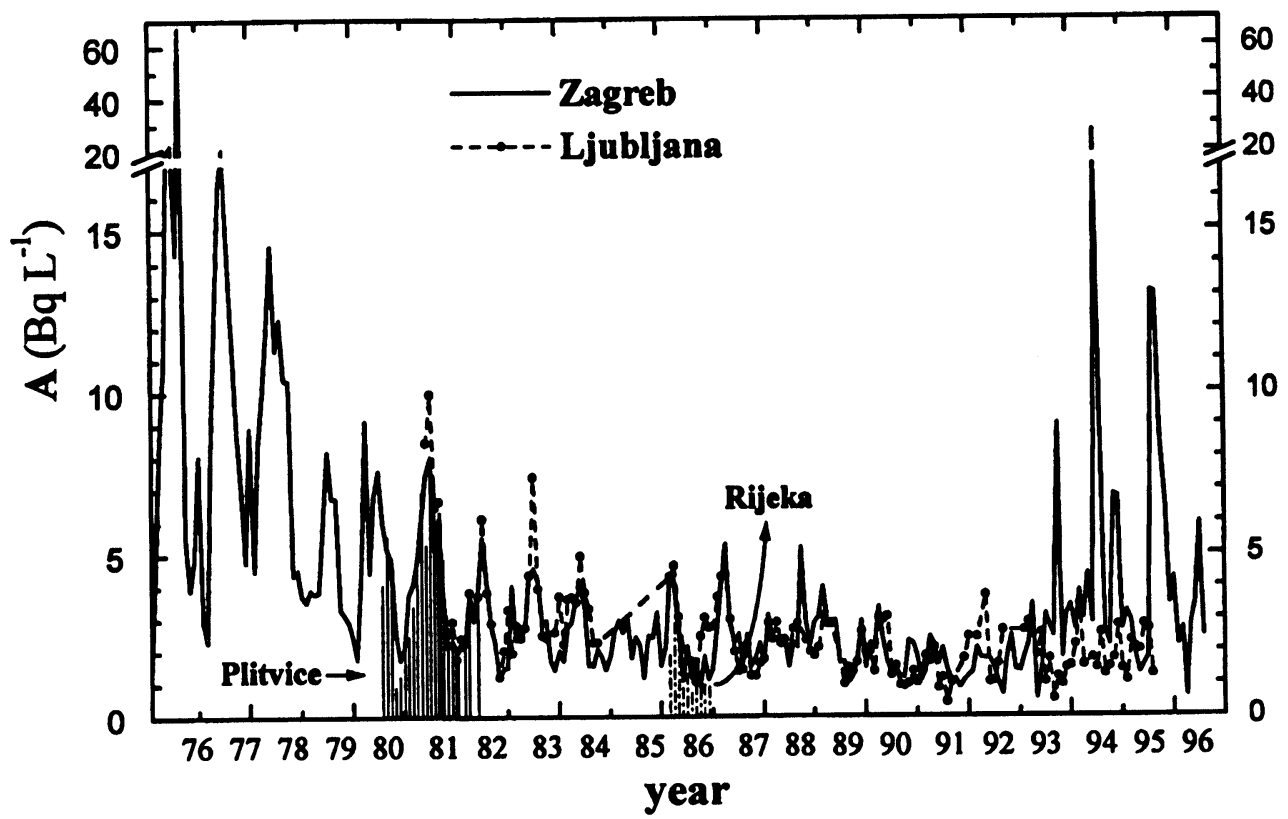

Fig. 5. A complete record of ${ }^{3} \mathrm{H}$ in precipitation at Zagreb-RBI for $1976-1996$, and at Ljubljana $1981-1995 .{ }^{3} \mathrm{H}$ in precipitation at stations Rijeka and Plitvice is also shown. The contaminated values from the Ljubljana station in the period 1984-1985 are not shown, while the ${ }^{3} \mathrm{H}$ activity measured at Zagreb-RBI in 1993-1996 is shown. See Figure 6 for noncontaminated values. 
water vapor has been measured since 1988 (Horvatincic et al. 1992). ${ }^{3} \mathrm{H}$ concentration in atmospheric water at the Institute ranged between 0.07 and $0.50 \mathrm{~Bq} \mathrm{~m}^{-3}$. These values were constantly higher than those at other locations $\left(0.02-0.04 \mathrm{~Bq} \mathrm{~m}^{-3}\right)$ due to local contamination with ${ }^{3} \mathrm{H}$, but the precipitation samples were not influenced. However, a much higher ${ }^{3} \mathrm{H}$ concentration of $2 \mathrm{~Bq} \mathrm{~m}^{-3}$ was observed in summer 1992 and constantly higher values have been measured since 1994, reaching even $4.4 \mathrm{~Bq} \mathrm{~m}^{-3}$ in November 1994 (Bistrović et al. 1994). This long, continuous contamination is reflected also in precipitation (Fig. 5). Therefore, we had to find a new location for precipitation sampling. In 1995, we started collecting samples at Puntijarka, on Mt. Medvednica, $988 \mathrm{~m}$ asl and 15 $\mathrm{km}$ north of the city, and in 1996 also at the Zagreb-GriX site at the Hydrometeorologic Institute, in the center of Zagreb (Fig. 1). In Figure 6 we compare the ${ }^{3} \mathrm{H}$ activity at all three sites in the Zagreb area for the period 1995-1996. ${ }^{3} \mathrm{H}$ activities in precipitation at stations Gric and Puntijarka are almost identical, while those in precipitation collected at the RBI site are several times higher. Maximal difference was measured in December 1995-January 1996 (factor of 30). The mean ${ }^{3} \mathrm{H}$ activity at the Zagreb-RBI site in 1995 and 1996 is 4.1 and $4.7 \mathrm{~Bq} \mathrm{~L}^{-1}$, respectively, significantly higher than that at Puntijarka (1.43 and 1.35 Bq L-1 in 1995 and 1996, respectively) or at Grix (1.23 Bq L$~^{-1}$ in 1996). Thus, it is evident that our old sampling site has been locally contaminated by ${ }^{3} \mathrm{H}$ since 1994 . In further analyses, the Zagreb-RBI data up to 1993 will be used, and for 1995 and 1996, data from Puntijarka will be taken as representative for Zagreb.

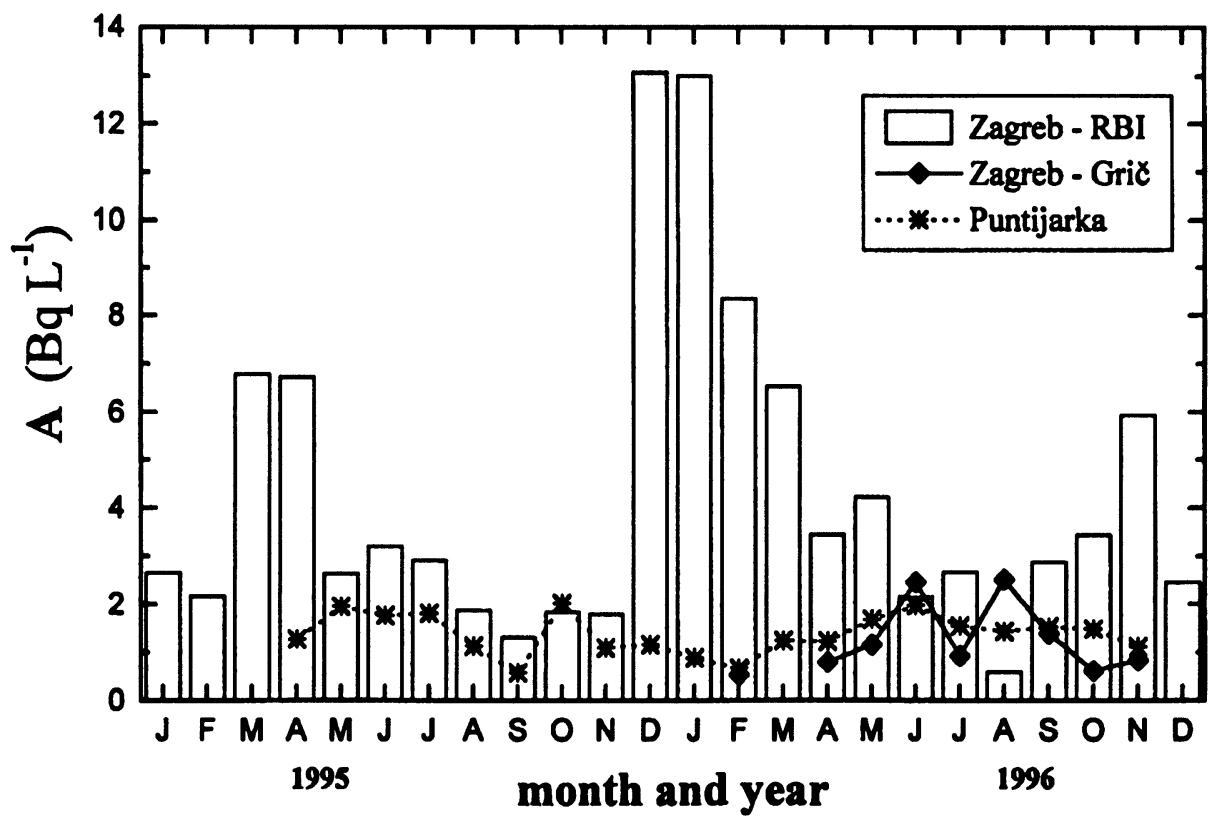

Fig. 6. A comparison of ${ }^{3} \mathrm{H}$ in precipitation from three locations (for 1995-1996) in the Zagreb area: ZagrebRBI, which is locally contaminated, and "clean" stations Zagreb-Gric and Puntijarka.

Characteristics of the long-term trend of ${ }^{3} \mathrm{H}$ in precipitation at both stations Zagreb and Ljubljana (Fig. 5) are typical for the Northern Hemisphere: a seasonal structure is superposed to the basic decrease, maximal activities are measured in early summer, and the minimal winter ${ }^{3} \mathrm{H}$ activities approached in the last years the natural, pre-bomb, level. Seasonal structure can be described as follows: In the period 1976-1992 the maximal ${ }^{3} \mathrm{H}$ activity at station Zagreb is observed between MayJuly, mostly in June. A secondary maximum (Rożanski et al. 1991) is also observed three times in 
January and February. Minimal ${ }^{3} \mathrm{H}$ activities were almost uniformly distributed from October to February, with a slightly more frequent occurrence in December. The seasonal distribution at the Ljubljana station is characterized by the most frequent appearance of the maximum in July, no secondary winter maximum is observed, and the minimum is most frequently measured in November, although it is distributed from October to March.

For shorter periods of several years, the ${ }^{3} \mathrm{H}$ content in monthly precipitation at two other locations in Croatia (Rijeka, Plitvice) was also recorded and is shown in Figure $5 .{ }^{3} \mathrm{H}$ concentration in precipitation at Plitvice (typical continental climate conditions) is well correlated with that at Zagreb and Ljubljana, and seasonal variations are similar to those at other continental stations from the temperate zone of the Northern Hemisphere (Rożanski et al. 1991). ${ }^{3} \mathrm{H}$ concentration in precipitation at the Adriatic coast (Rijeka) is, on the average, half of that in Zagreb. It is closely correlated with that in Genoa, while the correlation with the Zagreb station is poor.

In Figure 7, we show the mean yearly values, maximal and minimal ${ }^{3} \mathrm{H}$ activity during a year, and the ratio maximum/minimum for Zagreb precipitation. The ratio for noncontaminated sites ranges normally from 2.2 to 5.7, without a significant trend. For Ljubljana the ratio maximum/minimum ranges also from 2.3 to 5.5. The higher ratio in $1977(\sim 9)$ of Zagreb-RBI may be a consequence of some thermonuclear tests, which also caused transient increase of the ${ }^{3} \mathrm{H}$ level at other stations of the IAEA/ WMO network (Rożanski et al. 1991). Higher ratios were obtained also in the period 1994-1996, and they are attributed to local contamination at the Institute area. For non-contaminated stations, at Puntijarka the ratio was 3.4 in 1995 and 2.9 in 1996, and at station Zagreb-Gric the ratio was 4.6 in 1996.

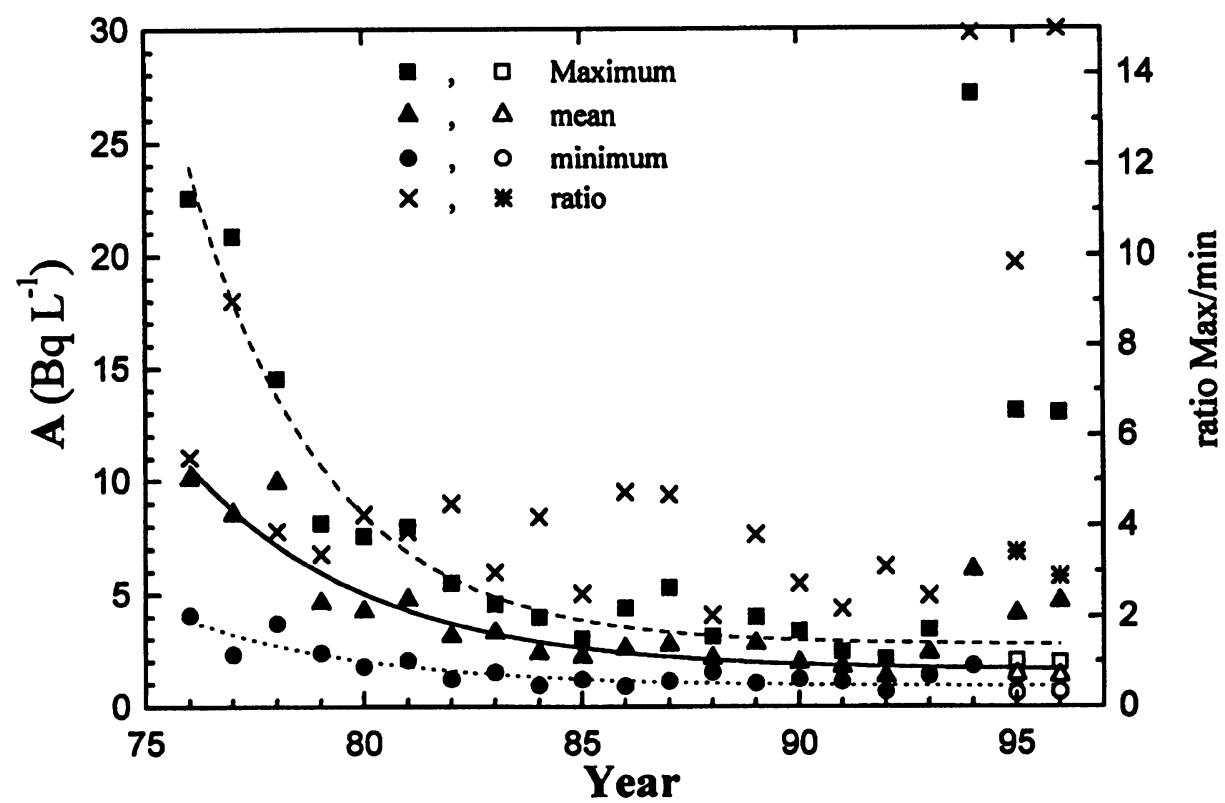

Fig. 7. The mean yearly ${ }^{3} \mathrm{H}$ activities in Zagreb precipitation, maximal and minimal values (left scale), as well as the ratio of maximum/minimum yearly ${ }^{3} \mathrm{H}$ activity (right scale). Full symbols represent the mean, maximum and minimum values at Zagreb-RBI, and open symbols the corresponding values at Puntijarka, while crosses and stars stand for the maximum and minimum ratios, respectively. Local contamination in the last few years caused a significant increase in the ratio for the Zagreb-RBI site, while the ratio at other two sites in the Zagreb area remained within the expected ranges. Full, broken and dotted lines represent the fits of the exponential decay function to the mean, maximal and minimal values, respectively. The Zagreb-RBI data for period 1976-1993 and the Puntijarka data for period 1995-1996 are used for the fits. 
The decrease in the mean, maximal and minimal ${ }^{3} \mathrm{H}$ activities in precipitation is very pronounced in the first decade of our record, while in the second decade all the values remain approximately constant (Fig. 7). A slight increase in 1986 and 1987 is observed both in Zagreb and Ljubljana, and also in Groningen precipitation (Meijer et al. 1994). An exponential decay function is fitted to the three sets of data, and the fitted curves are also shown in Figure 7. All the fitted curves support rather constant ${ }^{3} \mathrm{H}$ activity in precipitation during the last decade. Assuming that no additional ${ }^{3} \mathrm{H}$ will be released into the atmosphere in the future, we can predict approximate levels of ${ }^{3} \mathrm{H}$ in future precipitation: Mean values of $\sim 1.6 \mathrm{~Bq} \mathrm{~L}^{-1}$ are expected, and the ratio of expected maximal $\left(2.7 \mathrm{~Bq} \mathrm{~L}^{-1}\right)$ and minimal $\left(0.9 \mathrm{~Bq} \mathrm{~L}^{-1}\right)$ values is 3 . Any significant deviations from the expected values would then indicate some new ${ }^{3} \mathrm{H}$ releases from fusion facilities, medical and/or industrial facilities. Monitoring of ${ }^{3} \mathrm{H}$ activity in atmospheric water vapor, which is much more sensitive to local ${ }^{3} \mathrm{H}$ contamination than precipitation, may also help detecting local contamination.

\section{Reconstruction of Past Tritium Activity}

As a consequence of the disturbance in the equilibrium of ${ }^{3} \mathrm{H}$ atmospheric activity, ${ }^{3} \mathrm{H}$ may be used as a natural tracer in various fields, such as isotope hydrology, hydrometeorology, and environmental protection studies. Such investigations require the knowledge of ${ }^{3} \mathrm{H}$ activity in precipitation for the last $40-50$ yr. ${ }^{3} \mathrm{H}$ in precipitation was not measured in Zagreb until 1976, so the concentrations between 1953 and 1976 had to be reconstructed.

For reconstruction of the past ${ }^{3} \mathrm{H}$ activity, we used the long ${ }^{3} \mathrm{H}$ record at the Vienna-Hohe Varte station, as this is the nearest station with climatic conditions similar to those in our data. We found a good correlation between the yearly mean of ${ }^{3} \mathrm{H}$ activity in precipitation in Zagreb $\left(A_{Z}\right)$ and that in Vienna $\left(A_{V}\right)$ for the period 1976-1994:

$$
A_{Z}=0.8 \times A_{V}+0.4 \mathrm{~Bq} \mathrm{~L}^{-1}, r=0.985
$$

where $r$ is the correlation coefficient. By using this relation and the $A_{V}$ values for the period before 1976 , the mean ${ }^{3} \mathrm{H}$ activity in Zagreb precipitation for the period $1953-1975$ is estimated.

The analysis of ${ }^{3} \mathrm{H}$ activity in old wines of known vintage can also be a useful tool for reconstruction of the past ${ }^{3} \mathrm{H}$ activity in a certain area. We measured ${ }^{3} \mathrm{H}$ in several wine samples produced in northwestern Croatia in the period 1974-1986. The ${ }^{3} \mathrm{H}$ activity in three wine samples from the 1976-1986 period is well correlated with the measured mean ${ }^{3} \mathrm{H}$ activity in precipitation, and that of the two older wine samples with the ${ }^{3} \mathrm{H}$ activity estimated by using Equation (1) (Obelic et al. 1992).

We also measured the ${ }^{3} \mathrm{H}$ activity of the water produced by combustion of cellulose prepared from separated tree rings. ${ }^{3} \mathrm{H}$ activities in tree rings agree more or less with those in precipitation (estimated by using Eq. 1) for the most intensive bomb-test period, 1963-1967. However, the results for tree rings from the period 1975-1986 show remarkably high activities and practically no decrease in the last $15 \mathrm{yr}$ (Obelic et al. 1992). The reason for such a high ${ }^{3} \mathrm{H}$ activity measured in modern tree rings may be contamination introduced by the chemical procedure and chemicals used for cellulose separation. This assumption was checked by measuring the ${ }^{3} \mathrm{H}$ activity of the water from a tree-ring sample from the period before $1950 .{ }^{3} \mathrm{H}$ should have not been present in this sample, but we measured an activity equal to $37 \pm 1 \mathrm{~Bq} \mathrm{~L}^{-1}$. Such contamination is relatively small when the water from the tree-ring samples from the period 1963-1967 is concerned, but becomes more and more significant for more recent samples. Therefore, these data have not been used for the reconstruction of the past ${ }^{3} \mathrm{H}$ activity. 


\section{Measurements After the Chernobyl Accident}

The long-term records provide the data base against which the enhanced levels of radioactive isotopes can be compared. Measurements taken in April and May 1986 (after the Chernobyl accident) can illustrate the applications of such a long-term record.

After the accident at the Chernobyl NPP on April 26, 1986, the meteorological situation was such that air masses took the radioactive material towards the Baltic and the Scandinavian Peninsula during the first two days. Low pressure formed in the Genoa Bay on April 28, 1986 and caused a change in the wind direction, bringing radioactive material to central and southern Europe. Croatia was under the influence of a cold front on April 30, and the highest radioactive contamination was expected on May 1 and 2,1986 . After the first news about the accident was released, we began to collect daily samples of precipitation at three stations (Zagreb-RBI, and two locations in the Plitvice area).

Daily precipitation samples from April 29 and 30, 1986 showed no increased activity as compared with the monthly precipitation before the accident. There was no rain on May 1 , and on May $2,{ }^{3} \mathrm{H}$ concentrations about four times higher than normal were measured at all three sampling stations. In the following days, ${ }^{3} \mathrm{H}$ activity in the daily rain samples slowly decreased, reaching on May 8 the normal activity in spring time. The ${ }^{3} \mathrm{H}$ of the integrated precipitation sample collected from April 30 to May 15 was $5.6 \mathrm{~Bq} \mathrm{~L}^{-1}$, twice as much as expected for May. In comparison, in the samples collected in May 1985 and May 1987, the measured ${ }^{3} \mathrm{H}$ activity was $3.0 \pm 0.2 \mathrm{~Bq} \mathrm{~L}^{-1}$, and $4.1 \pm 0.2$ $\mathrm{Bq} \mathrm{L}^{-1}$, respectively. For the samples collected on May $16-31,1986,{ }^{3} \mathrm{H}$ activity was again "normal": $3.22 \pm 0.23 \mathrm{~Bq} \mathrm{~L}^{-1}$.

The influence of radioactive air masses containing higher ${ }^{3} \mathrm{H}$ activity was very short-lived over northwestern Croatia, and the amount of precipitation was not abundant, leading to the conclusion that contamination of water in aquifers should be negligible. Indeed, in tapwater collected in Zagreb, as well as in several wells used for the local water supply in the Plitvice area, no increase in ${ }^{3} \mathrm{H}$ activity was observed.

\section{Stable Isotopes ${ }^{2} \mathrm{H}$ and ${ }^{18} \mathrm{O}$ in Precipitation}

In this section, we analyze the long-term stable isotope data record at the Zagreb and Ljubljana stations. The average yearly amount of precipitation is $840 \mathrm{~L} \mathrm{~m}^{-2}$ and $1474 \mathrm{~L} \mathrm{~m}^{-2}$, and the average yearly temperature is $11.0^{\circ} \mathrm{C}$ and $9.9^{\circ} \mathrm{C}$, in Zagreb and Ljubljana, respectively. The nearest continental station from the IAEA-WMO network is Vienna-Hohe Varte, $\left(909 \mathrm{~L} \mathrm{~m}^{-2}, 10.7^{\circ} \mathrm{C}\right)$, and our results are compared mostly with this station.

In Figure 8, we present for the Zagreb station long-term monthly values for temperature $\left(t_{m}\right)$, amount of precipitation $\left(P_{m}\right)$, and stable isotope contents $\delta^{2} \mathrm{H}_{\mathrm{m}}$ and $\delta^{18} \mathrm{O}_{\mathrm{m}}$ averaged over $20 \mathrm{yr}, 1976-1996$. (We denote the long-term monthly mean values with a subscript " $\mathrm{m}$ ").) Precipitation values are rather uniformly distributed over the whole year with no seasonal maximum, while the mean monthly values of temperature and stable isotope contents show distinct seasonal behavior. Therefore, no correlation between the amount of precipitation and stable isotope data is obtained. The same conclusion is valid also for the Ljubljana precipitation samples, and therefore only figures representing data from Zagreb are shown in this section. Such a situation is typical for continental stations at the northern hemisphere (Rożanski et al. 1993). Maximal temperature, as well as the highest $\delta^{2} \mathrm{H}_{\mathrm{m}}$ and $\delta^{18} \mathrm{O}_{\mathrm{m}}$ values, are obtained in July, and the lowest in January (in February at Ljubljana). 
Z A G R E B, $1976-1996$

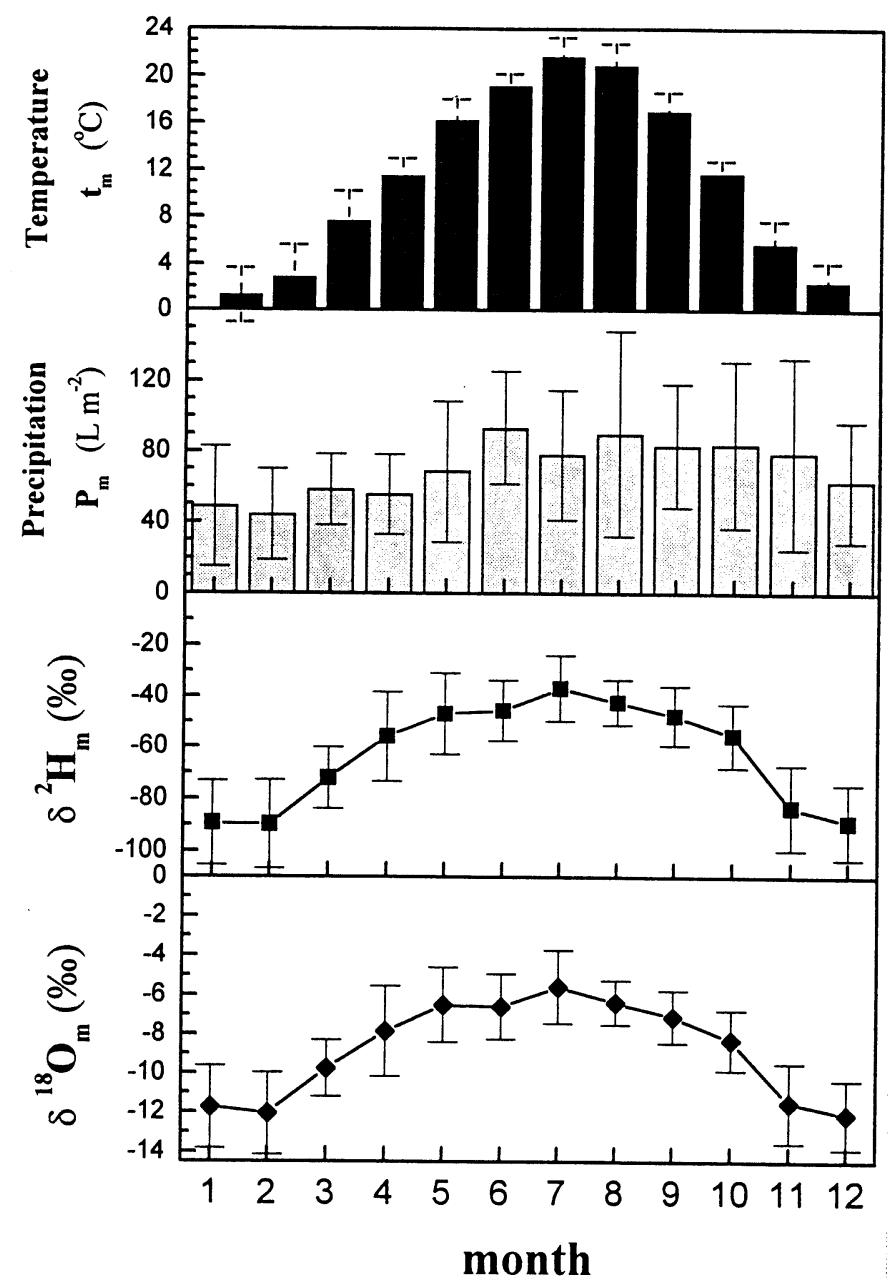

Fig. 8. Long-term monthly mean values (with $\pm 1 \sigma$, where $\sigma$ is standard deviation) of temperature $\left(t_{m}\right)$, amount of precipitation $\left(P_{m}\right), \quad \delta^{18} \mathrm{O}_{\mathrm{m}}$ and $\delta^{2} \mathrm{H}_{\mathrm{m}}$ at the Zagreb-RBI station

Such good seasonality observed in both stable isotopes and temperature enables us to perform a linear regression analysis of $\delta^{18} \mathrm{O} v s$. the mean monthly local surface air temperatures (Fig. 9). When all the monthly data are included in the regression analysis, the following correlation is obtained

$$
\delta^{18} \mathrm{O}=(0.325 \pm 0.016) t-(12.62 \pm 0.22) \% o, r=0.83, n=183,
$$

where $t$ is the surface air temperature, $r$ is the correlation coefficient, and $n$ is the number of data pairs. For the long-term mean monthly values, the following equation is obtained

$$
\delta^{18} \mathrm{O}_{m}=(0.327 \pm 0.024) t_{m}-(12.55 \pm 0.32) \% o, r=0.975, n=12 \text {. }
$$

The slope and the intercept are in both equations equal within given errors. Both lines are shown in Figure 9. For the Ljubljana station, the corresponding equations are

$$
\begin{aligned}
\delta^{18} \mathrm{O} & =(0.30 \pm 0.02) t-(12.00 \pm 0.26) \% o, r=0.78, n=138, \\
\delta^{18} \mathrm{O}_{m} & =(0.295 \pm 0.021) t_{m}-(12.1 \pm 0.3) \% o, r=0.975, n=12 .
\end{aligned}
$$




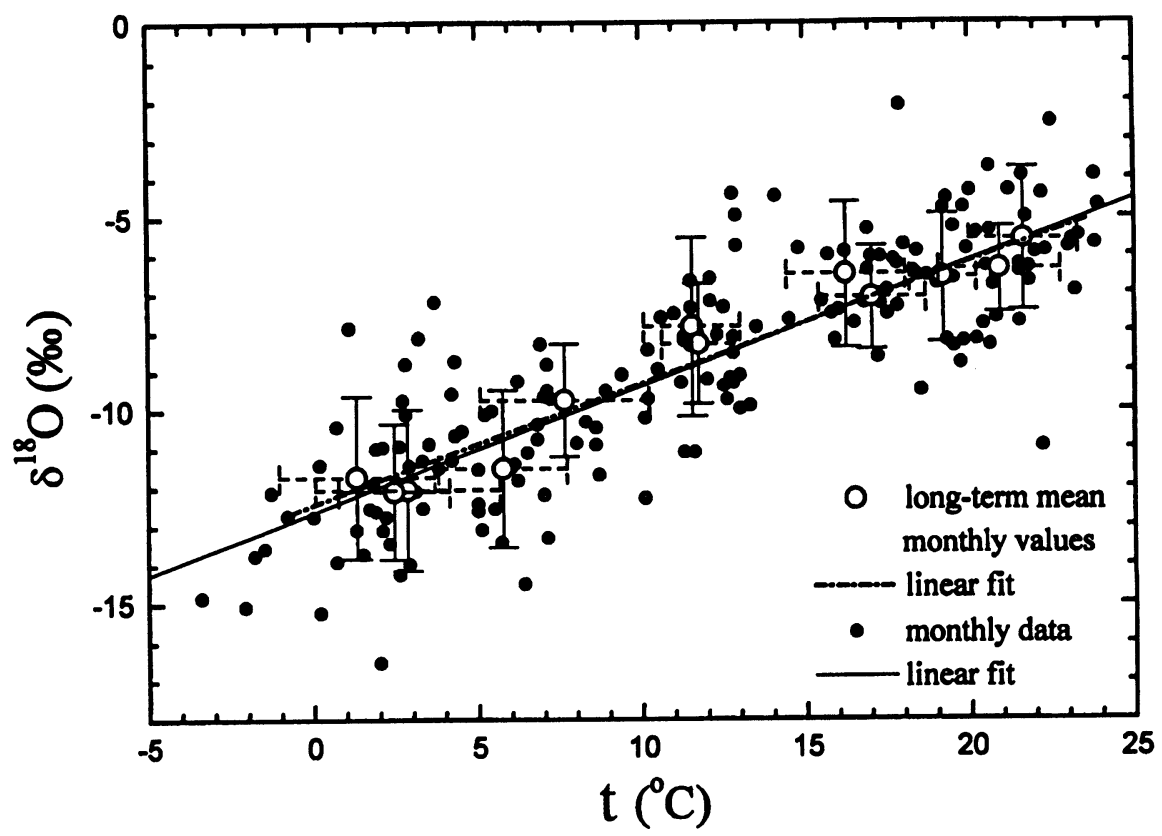

Fig. 9. Correlation between the $\delta^{18} \mathrm{O}$ in precipitation and the local surface air temperature $t$ at station Zagreb-RBI. Full symbols represent the monthly data, and open symbols with error bars are the long-term mean monthly values $\left(t_{m}\right.$ and $\left.\delta^{18} \mathrm{O}_{m}\right)$. Linear fits to all data and to the long-term mean monthly values are shown.

The correlations between long-term $\delta^{18} \mathrm{O}$ values and the local surface air temperature are of great interest because of their possible application to paleoclimatic studies. The first relations of this kind were obtained by Dansgaard (1964) for mid- and high northern latitude coastal stations, and the slope was $0.69 \%$ per ${ }^{\circ} \mathrm{C}$ for $\delta^{18} \mathrm{O}$. Later, Rożanski et al. (1993) used the long-term monthly mean $\delta^{18} \mathrm{O}_{\mathrm{m}}$ and $t_{m}$ values from the mid-latitude stations in the Northern Hemisphere to determine the slope of the best fit line of $0.31 \%$ per ${ }^{\circ} \mathrm{C}$. This value is much lower than the one previously obtained by Dansgaard (1964), and it is in very good agreement with the slopes we obtained for stations Zagreb and Ljubljana (Eqs. 2-5). We should mention that the relationship $\delta^{18} \mathrm{O} v s . t$ is linear only within a limited temperature range. Thus, the long-term seasonal correlation between $\delta^{18} \mathrm{O}$ and surface air temperature derived for the stations of the IAEA/WMO global network situated between $40^{\circ} \mathrm{N}$ and $60^{\circ} \mathrm{N}$ showed that the $\delta^{18} \mathrm{O}-t$ relationship is nonlinear, with a higher slope for lower $\delta^{18} \mathrm{O}$ and $t$ and only small changes of $\delta^{18} O$ with $t$ temperatures (Rożanski 1993).

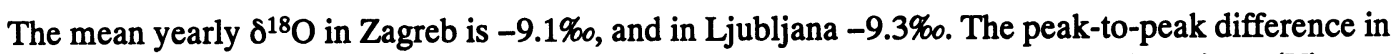
$\delta^{18} \mathrm{O}_{\mathrm{m}}$ for both stations is $\sim 6 \%$. Such a value is characteristic for continental stations (Vienna, Kraków) $2000 \mathrm{~km}$ away from the main source of water, the Atlantic Ocean (Rożanski et al. 1993). Lower $\delta^{18} \mathrm{O}$ values, especially during winter months, and larger amplitudes of seasonal $\delta^{18} \mathrm{O}$ and $\delta^{2} \mathrm{H}$ variations with increased distance from the ocean are usually described as the continental effect.

The large altitude difference between the station Puntijarka (988 $\mathrm{m}$ asl) and the Zagreb stations Gric and RBI (see Table 1) enables us to estimate the effect of altitude in our region. The difference in the mean yearly $\delta^{18} \mathrm{O}$ values at Puntijarka and Zagreb-Grix is -2\%o, and between Puntijarka and Zagreb$\mathrm{RBI}$ is $-2.76 \%$. Therefore, an average decrease in $\delta^{18} \mathrm{O}$ value of $-0.28 \%$ per $100 \mathrm{~m}$ altitude increase 
is estimated. The value is in good agreement with the global average value of $-0.2 \%$ per $100 \mathrm{~m}$ altitude difference (Rożanski et al. 1993).

The close proportionality between $\delta^{2} \mathrm{H}$ and $\delta^{18} \mathrm{O}$ in meteoric waters is commonly known as the global meteoric water line (GMWL):

$$
\delta^{2} \mathrm{H}=8 \delta^{18} \mathrm{O}+10 \% \text {. }
$$

This relation represents the base of many hydrological applications, because distinct deviations from the slope 8 indicate changes in isotopic composition due to evaporation, and the deviations from the GMWL indicate various isotopic exchange processes within an aquifer. The knowledge of the local meteoric water line (LMWL) is therefore of the utmost importance for any hydrogeological application of stable isotope data. We obtained the LMWLs for the station Zagreb-RBI (Fig. 10) by using all monthly data and by using the long-term monthly mean values:

all data:

$$
\delta^{2} \mathrm{H}=(7.9 \pm 0.1) \delta^{18} \mathrm{O}+(6.9 \pm 0.9) \%, n=194, r=0.985
$$

long-term:

$$
\delta^{2} \mathrm{H}_{\mathrm{m}}=(8.1 \pm 0.2) \delta^{18} \mathrm{O}_{\mathrm{m}}+(9.1 \pm 1.9) \%, n=12, r=0.996
$$

The corresponding LMWLs for Ljubljana are

$$
\begin{array}{ll}
\text { all data: } & \delta^{2} \mathrm{H}=(8.1 \pm 0.1) \delta^{18} \mathrm{O}+(11.1 \pm 0.8) \% 0, n=149, r=0.992 \\
\text { long-term: } & \delta^{2} \mathrm{H}_{\mathrm{m}}=(8.3 \pm 0.3) \delta^{18} \mathrm{O}_{\mathrm{m}}+(12.4 \pm 2.2) \% o, n=12, r=0.995 .
\end{array}
$$

The slope of the LMWL for Ljubljana is slightly higher than that for the Zagreb LMWL, and the intercept is somewhat higher. But the relations are not very different from those of the GMWL,

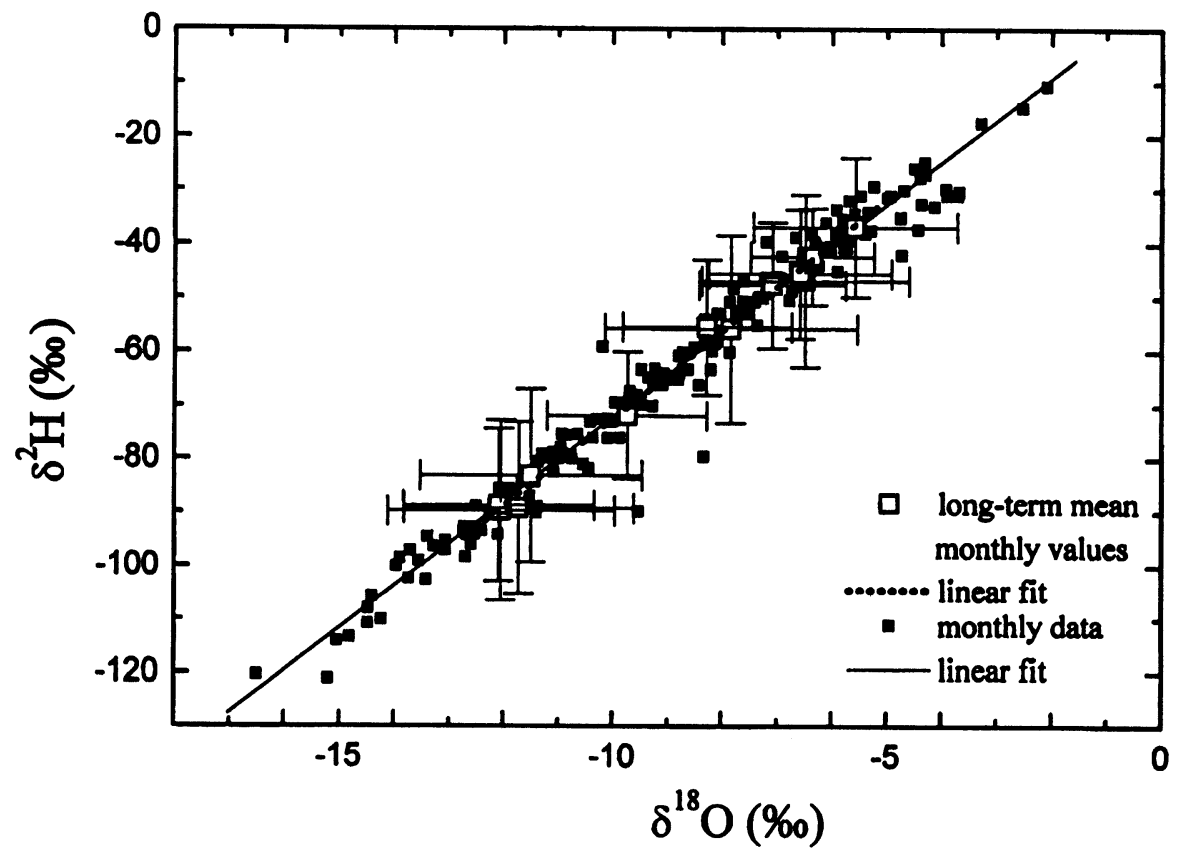

Fig. 10. Local meteoric water line (LMWL) for the Zagreb-RBI station. Black squares represent the monthly data, and white squares with error bars are the long-term mean monthly values $\left(\delta^{18} \mathrm{O}_{m}\right.$ and $\left.\delta^{2} \mathrm{H}_{m}\right)$. Linear fits to all data and to the long-term mean monthly values are shown. 
showing that the main source of precipitation is the Atlantic Ocean, and that no significant evaporation and isotope-exchange processes occur below the cloud (Rożanski et al. 1993).

The deviation of the individual data point from the GMWL is usually described as the deuterium excess d, where

$$
\mathrm{d}=\delta^{2} \mathrm{H}-8 \times \delta^{18} \mathrm{O} .
$$

The deuterium excess reflects the specific source conditions during water vapor formation and it may therefore indicate different sources of vapor. For example, the precipitation originating from the Mediterranean Sea is characterized by distinctly higher deuterium excess than that originating from the Atlantic Ocean. The mean deuterium excess value for the Zagreb-RBI station is $7.8 \pm 4.0$ $(n=194)$, with almost normal distribution between -5 and +15 . However, several monthly values are characterized by the values $>20$, indicating that the precipitation during these particular months originated predominantly from the Mediterranean Sea. No seasonal fluctuations in the deuterium excess are observed. For the Ljubljana station, the mean deuterium excess value is $9.7 \pm 2.9$, distributed between 0 and 16, with no obvious seasonal variations, and no unusually high values.

\section{CONCLUSION}

In this paper, we presented the complete 20 -yr-long record of environmental isotope data $\left({ }^{2} \mathrm{H},{ }^{3} \mathrm{H}\right.$, ${ }^{14} \mathrm{C},{ }^{18} \mathrm{O}$ ) measured in Zagreb and collected at various stations in Croatia and Slovenia. The clean-air sites, the sites around the NPP and the sites in the industrialized area are included in the monitoring. Both radioactive isotopes $\left({ }^{3} \mathrm{H},{ }^{14} \mathrm{C}\right)$ show a continuous decrease in mean yearly values and superposed seasonal fluctuations. Relatively large peak-to-peak fluctuations in $\Delta^{14} \mathrm{C}$ in the Zagreb area are caused by the introduction of fossil-fuel carbon into the atmosphere during the winter months.

A reconstruction of atmospheric ${ }^{14} \mathrm{C}$ activity was done by measuring tree rings. A good correlation with the measured mean yearly $\Delta^{14} \mathrm{C}$ in atmospheric $\mathrm{CO}_{2}$ was obtained. The long-term ${ }^{14} \mathrm{C}$ data (1964-1996) were fitted by the exponential decrease function, and the recent years (1983-1996) were fitted by a linear function. A linear function fitted to the mean yearly atmospheric ${ }^{14} \mathrm{C}$ activity at Zagreb gave a decrease of $12.2 \%$ per year, and thus predicted that in 2000 in industrialized areas, the "natural" (pre-bomb-pre-industrial) level of $\Delta^{14} \mathrm{C}=0 \%$ can be reached, if no new sources of either very active or fossil-fuel ${ }^{14} \mathrm{C}$ are introduced into the atmosphere.

In order to obtain approximate ${ }^{3} \mathrm{H}$ values for hydrological applications, we reconstructed the past ${ }^{3} \mathrm{H}$ activity in local precipitation by correlating our data with those from Vienna. The trend in mean, maximal and minimal yearly ${ }^{3} \mathrm{H}$ activities in precipitation (1976-1996) is also analyzed by exponential decay functions. If no new ${ }^{3} \mathrm{H}$ is introduced into the atmosphere in the future, then future ${ }^{3} \mathrm{H}$ activity measured in precipitation should not be significantly different from the values measured in recent years. The predicted future ${ }^{14} \mathrm{C}$ and ${ }^{3} \mathrm{H}$ levels may later help determine any accidental contamination (local or global), or increased levels of continuous releases from various nuclear facilities. We found that atmospheric water vapor was very sensitive to local sources of ${ }^{3} \mathrm{H}$, and thus it can serve as a good indicator of local contamination. Simultaneous measurements of ${ }^{3} \mathrm{H}$ concentration in precipitation and in atmospheric water vapor helped to identify the local contamination with ${ }^{3} \mathrm{H}$, and the new non-contaminated sampling sites for precipitation were found.

Long-term stable isotope records at two stations, Zagreb and Ljubljana, enabled us to determine local meteoric water lines, as well as the relation between $\delta^{18} \mathrm{O}$ in precipitation and the local surface air temperature. Both relations are important for hydrological and paleoclimatic applications. 


\section{ACKNOWLEDGMENTS}

This work was performed under Project Grant PO-207 from the Ministry of Science of the Republic of Croatia. We express our thanks to the former leader of the laboratory, Dr. Dušan Srdoð (Columbia University, NY) for his scientific contributions and continuous interest in our work. Measurement of stable isotopes in precipitation samples at the Jožef Stefan Institute in Ljubljana is greatly appreciated. We thank I. Levin for providing the tabulated $\Delta^{14} \mathrm{C}$ data for the Schauinsland station.

\section{REFERENCES}

Bistrovic, R., Krajcar Bronic, I., Horvatincić, N., Obelic, B. and Vekic, B. 1994 Tritium as an indicator of a local contamination. Proceedings of the 2nd Symposium of the Croatian Radiation Protection Association, Zagreb, Croatia: 101-104 (in Croatian).

Dansgaard, W. 1964 Stable isotopes in precipitation. Tellus 16: 436-468.

Horvatincic, N. 1980 Radiocarbon and tritium measurements in water samples and application of isotopic analyses in hydrology. Fizika 12(S2): 201-218.

Horvatinčic, N., Krajcar Bronić, I., Pezdič, J., Srdoč, D. and Obelic, B. 1986 The distribution of radioactive $\left({ }^{3} \mathrm{H},{ }^{14} \mathrm{C}\right)$ and stable $\left({ }^{2} \mathrm{H},{ }^{18} \mathrm{O}\right)$ isotopes in precipitation, surface and groundwaters of NW Yugoslavia. Nuclear Instruments and Methods in Physics Research B17: 550-553.

Horvatincic, N., Krajcar Bronic, I., Obelic, B. and Srdox, D. 1989 A comparison of tritium in precipitation and in air moisture. In Radiation Protection: Selected Topics. Proceedings of the International Symposium, Dubrovnik, Croatia: 443-448.

Horvatincic, N., Srdoc, D., Obelic, B. and Krajcar Bronic, I. 1990 Radiocarbon dating of intercomparison samples at the Zagreb Radiocarbon Laboratory. Radiocarbon 32(3): 295-300.

Horvatinčić, N., Krajcar Bronic, I. and Obelic, B. 1992 Tritium in the atmosphere over Croatia and Slovenia. Proceedings of the International Symposium on Environmental Contamination in Central and East Europe, Budapest, Hungary: 163-165.

Horvatincic, N., Krajcar Bronić, I., Obelić, B. and Bistrovic, R. 1996a Long-time atmospheric tritium record in Croatia. Acta Geologica Hungarica 39(Suppl.): 8184.

Horvatinčic, N., Krajcar Bronic, I. and Obelic, B. 1996b Long-time atmospheric ${ }^{3} \mathrm{H}$ and ${ }^{14} \mathrm{C}$ record in Croatia, Proceedings of the 9th Congress of International Radiation Protection Association (IRPA 9 Congress) Vienna: 676-678.

Hut, G. 1986 IAEA Report: 1986 Intercomparison of low-level tritium measurement in water.

IAEA 1969, 1970, 1971, 1973, 1975, 1979, 1983, 1986, 1990, 1994 Environmental Isotope Data Nos. 1-10: World Survey of Isotope Concentration in Precipitation, Technical Reports Series Nos. 69, 117, 129, 147, 165, 192, 226, 264, 311, 371.
Kozák, K. and Rank, D. 1981 A feasibility study on the retrospective evaluation of anomalous local tritium fallout by the analysis of tree rings from selected districts in Austria and Hungary. Final Report to the IAEA, Contracts 3451/RB and 3452/RB: 1-31.

Kozák, K., Obelić, B. and Horvatinžic, N. 1989 Tritium and ${ }^{14} \mathrm{C}$ in tree rings of the last three decades. In Long, A., Srdox, D. and Kra, R. S., eds., Proceedings of the 13th International ${ }^{14} \mathrm{C}$ Conference. Radiocarbon 31 (3): 766-770.

Krajcar Bronić, I., Horvatinčic, N., Srdoc, D. and Obelic, B. 1992 Tritium concentration in the atmosphere over NW Yugoslavia. In Povinec, P., ed., Proceedings of the 14th Europhysics Conference on Nuclear Physics, Bratislava, Slovakia. Rare Nuclear Processes. Singapore, World Scientific: 381-386.

Krajcar Bronic, I., Horvatinčc, N., Obelic, B. and Bistrovic, R. 1995 Radiocarbon intercomparison studies at the Ruđer Boskovic Institute. In Cook, G. T., Harkness, D. D., Miller, B. F. and Scott, E. M., eds., Proceedings of the 15 th International ${ }^{14} \mathrm{C}$ Conference. $R a$ diocarbon 37(3): 805-811.

Krajcar Bronic, I., Obelic, B., Srdoč, D. and Hernaus, E. 1986 Tritium Activity in Precipitation and in Tap Water of NW Yugoslavia after the Chernobyl Accident. Proceedings of the 4th European Congress of IRPA, Salzburg: 761-764.

Kuc, T. and Zimnoch, M. 1998 Changes of the $\mathrm{CO}_{2}$ sources and sinks in a polluted urban area (southern Poland) over the last decade, derived from the carbon isotope composition. Radiocarbon, this issue.

Levin, I., Bösinger, R., Bonani, G., Francey, R. J., Kromer, B., Münnich, K. O., Suter, M., Trivett, N. B. A. and Wölfli, W. 1992 Radiocarbon in atmospheric carbon dioxide and methane: Global distribution and trends. In Taylor, R. E., Long, A. and Kra, R. S., eds., Radiocarbon After Four Decades: An Interdisciplinary Perspective. New York, Springer-Verlag: 503-518.

Levin, I., Graul, R. and Trivett, N. B. A. 1995 Long-term observations of atmospheric $\mathrm{CO}_{2}$ and carbon isotopes at continental sites in Germany. Tellus 47B: 23-34.

Levin, I. and Kromer, B. 1997 Twenty years of high-precision atmospheric ${ }^{14} \mathrm{CO}_{2}$ observations at Schauinsland station, Germany. Radiocarbon 39(2): 205-218.

Levin, I., Münnich, K. O. and Weiss, W. 1980 The effect of anthropogenic $\mathrm{CO}_{2}$ and ${ }^{14} \mathrm{C}$ sources on the distribu- 
tion of ${ }^{14} \mathrm{C}$ in the atmosphere. In Stuiver, M. and Kra, R. S., eds., Proceedings of the 10 th International ${ }^{14} \mathrm{C}$ Conference. Radiocarbon 22(2): 379-391.

McNeely, R. 1994 Long-term environmental monitoring of ${ }^{14} \mathrm{C}$ levels in the Ottawa region. Environment International 20: 675-679.

Meijer, H. A. J., van der Plicht, H., Gislefoss, J. S. and Nydal, R. 1994 Comparing long-term atmospheric ${ }^{14} \mathrm{C}$ and ${ }^{3} \mathrm{H}$ records near Groningen, the Netherlands with Fruholmen, Norway and Izaña, Canary Islands ${ }^{14} \mathrm{C}$ stations. Radiocarbon 37(1): 39-50.

Obelic, B., Krajcar Bronic, I., Srdoc, D. and Horvatinzic, N. 1986 Environmental ${ }^{14} \mathrm{C}$ levels around the 632 MWe Nuclear Power Plant Krško in Yugoslavia. Radiocarbon 28(2A): 644-648.

Obelic, B., Krajcar Bronic, I., Horvatinčic, N. and Srdoð, D. $1987{ }^{14} \mathrm{C}$ activity in plants and in the atmosphere during the last decade. In Markovic, P., Horvat, $\boxplus$. and Markovic, S., eds., Proceedings of the 14th Regional Congress of IRPA, Kupari 1987: 287-290.

Obelic, B., Horvatincic, N., Krajcar Bronic,, I. and Kozák, K. 1992 Concentration of ${ }^{14} \mathrm{C}$ and ${ }^{3} \mathrm{H}$ in treerings from Plitvice National Park region. In Richter, P. I. and Herndon, R. C., eds., Proceedings of the International Symposium on Environmental Contamination in Central and East Europe, Budapest, 1992: 505507.

Olsson, I. U. 1989 Recent ${ }^{14} \mathrm{C}$ activity in the atmosphere, "clean air" and the Chernobyl effect. In Long, A., Kra, R. S. and Srdoc, D., eds., Proceedings of the 13th International ${ }^{14} \mathrm{C}$ Conference. Radiocarbon 31(3): 740 746.

Otlet, R. L., Fulker, M. J. and Walker, A. J. 1992 Environmental impact of atmospheric carbon-14 emissions resulting from the nuclear energy cycle. In Taylor, $R$.
E., Long, A. and Kra, R. S., eds., Radiocarbon After Four Decades: An Interdisciplinary Perspective. New York, Springer-Verlag: 519-534.

Rozanski, K., Stichler, W., Gonfiantini, R., Scott, E. M., Beukens, R. P., Kromer, B. and van der Plicht, J. 1992 The IAEA Intercomparison exercise 1990. In Long, A. and Kra, R. S., eds., Proceedings of the 14th International ${ }^{14} \mathrm{C}$ Conference. Radiocarbon 34(3): 506519.

Rożanski, K., Gonfiantini, G. and Araguas-Araguas, L. 1991 Tritium in the global atmosphere: Distribution patterns and recent trends. Journal of Physical Geography 17(Suppl.): S523-536.

Rożanski, K., Araguas-Araguas, L. and Gonfiantini, R. 1993 Isotopic patterns in modern global precipitation. Geophysical Monograph 78: 1-36.

Segl, M., Levin, I., Schoch-Fischer, H., Münnich, M., Kromer, B., Tschiersch, J. and Münnich, K. O. 1983 Anthropogenic ${ }^{14} \mathrm{C}$ variations. Radiocarbon $25(2)$ : 583-592.

Scott, E. M., Harkness, D. D., Miller, B. F., Cook, G. T. and Baxter, M. S. 1992 Announcement of a further international intercomparison exercise. In Long, A. and Kra, R. S., eds., Proceedings of the 14th International ${ }^{14} \mathrm{C}$ Conference. Radiocarbon 34(3): 528-532.

Scott, E. M., Long, A. and Kra, R. S., eds. 1990 Proceedings of the International Workshop on Intercomparison of Radiocarbon Laboratories. Radiocarbon 32(3): 253-397.

Stuiver, M. and Polach, H. A. 1977 Discussion: Reporting of ${ }^{14} \mathrm{C}$ data. Radiocarbon 19(3): 355-363.

Srdoc, D., Breyer, B. and Sliepcević, A. 1971 Ruder Boßkkovic Institute radiocarbon measurements I. $R a$ diocarbon 13(1): 135-140. 
Plate 1: Voelker et al., Figure 6

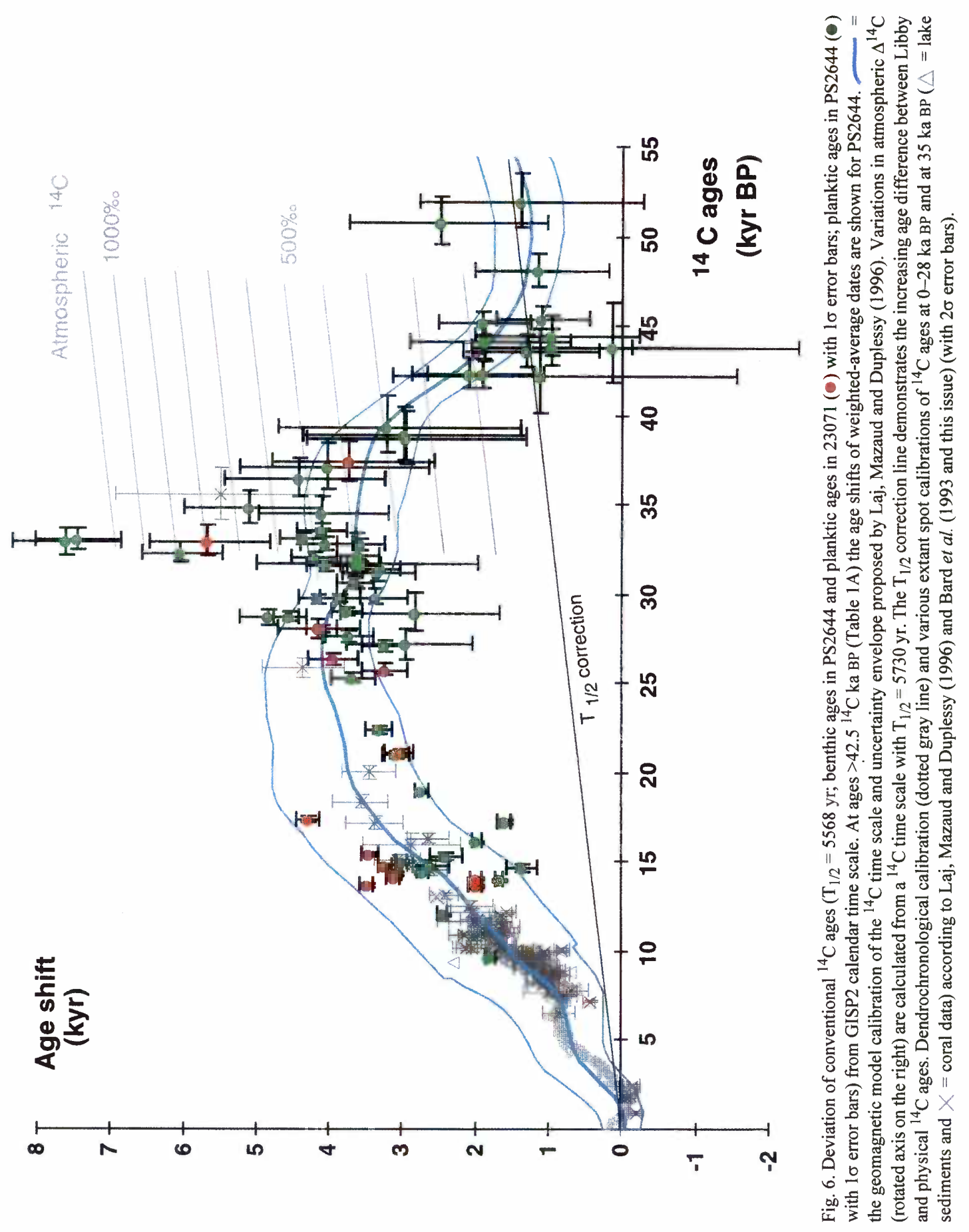


Plate 2: Currie et al., Figure 1

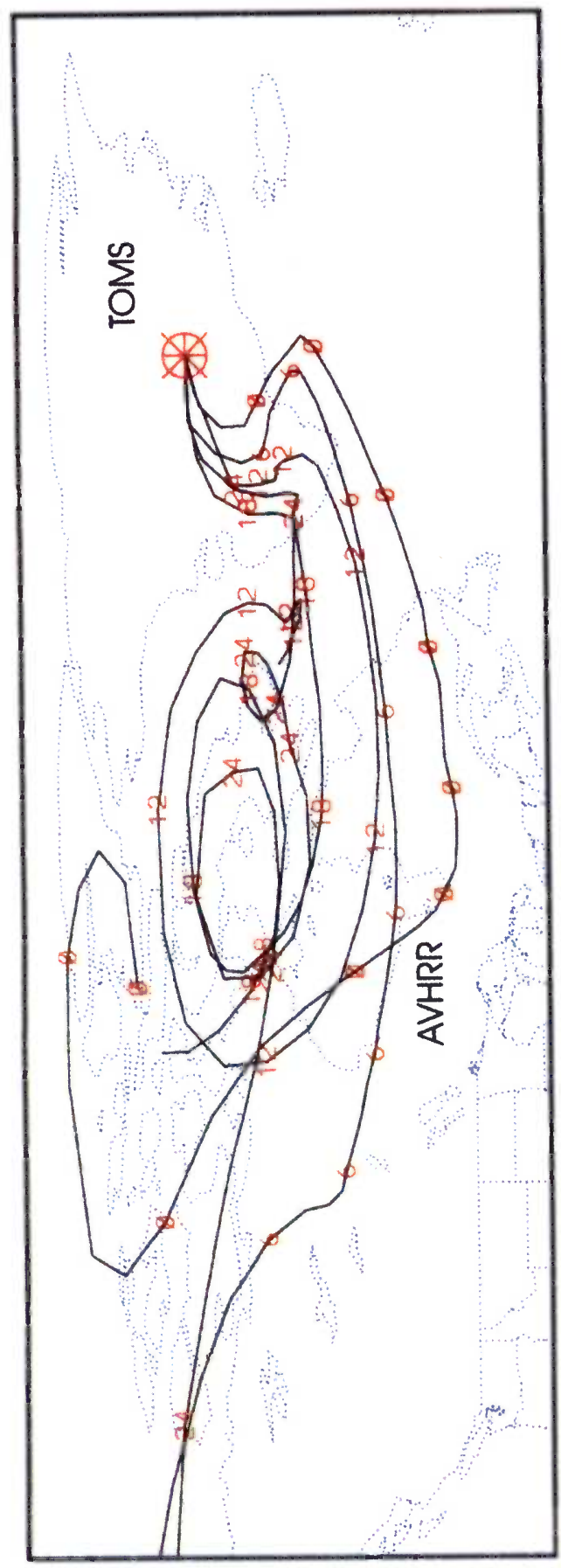

$\widehat{\mathbf{m}}$

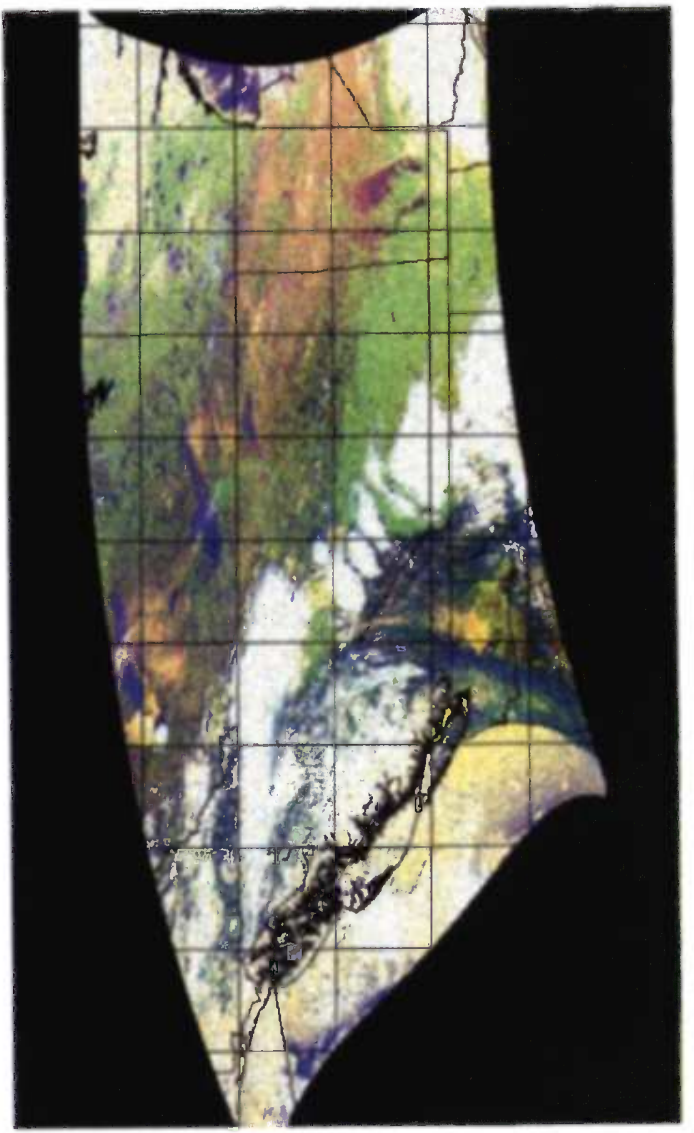

$\frac{\frac{\alpha}{\alpha}}{\frac{1}{\alpha}}$ 

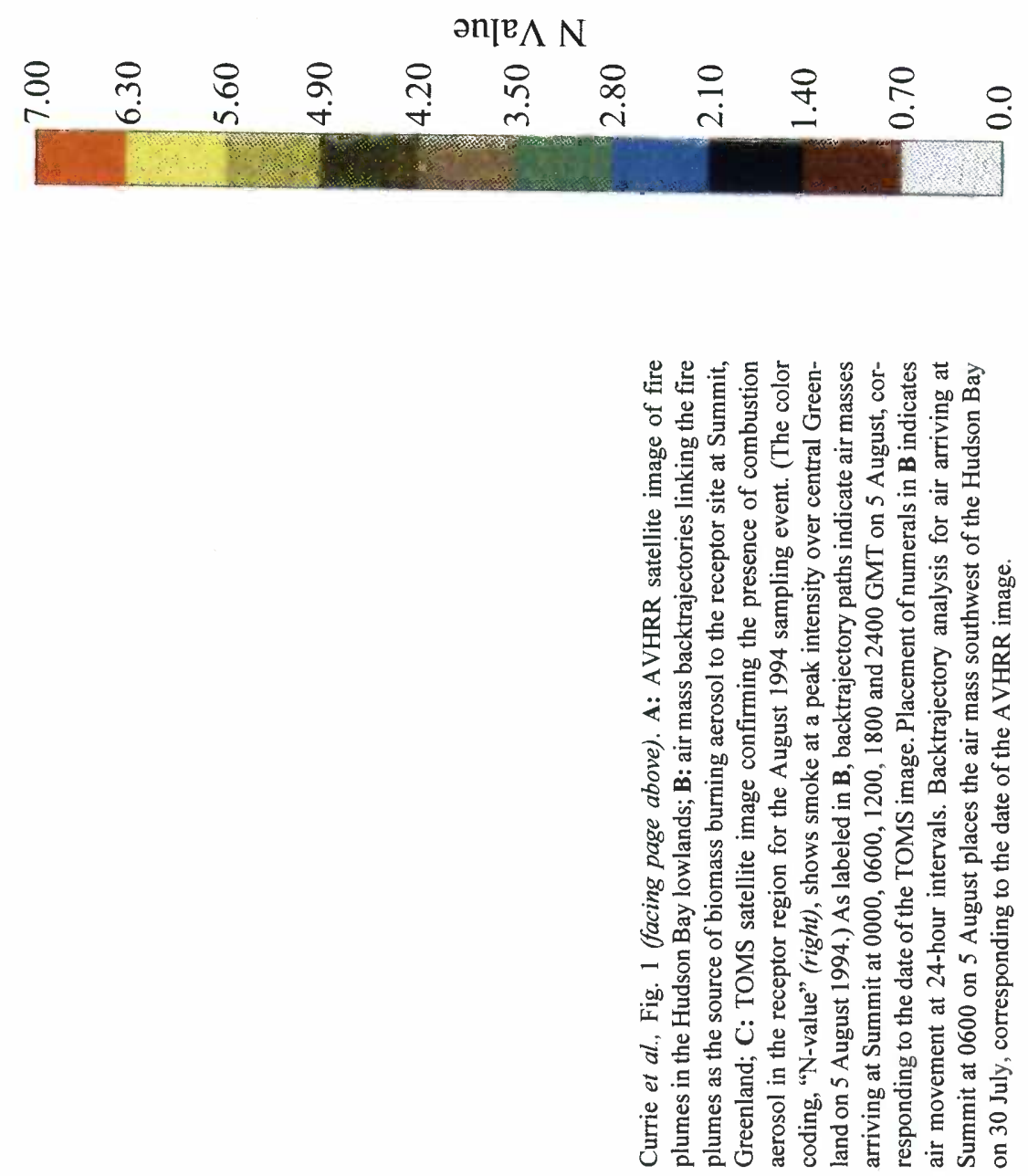


\section{Plate 3: Currie et al., Figure 2}

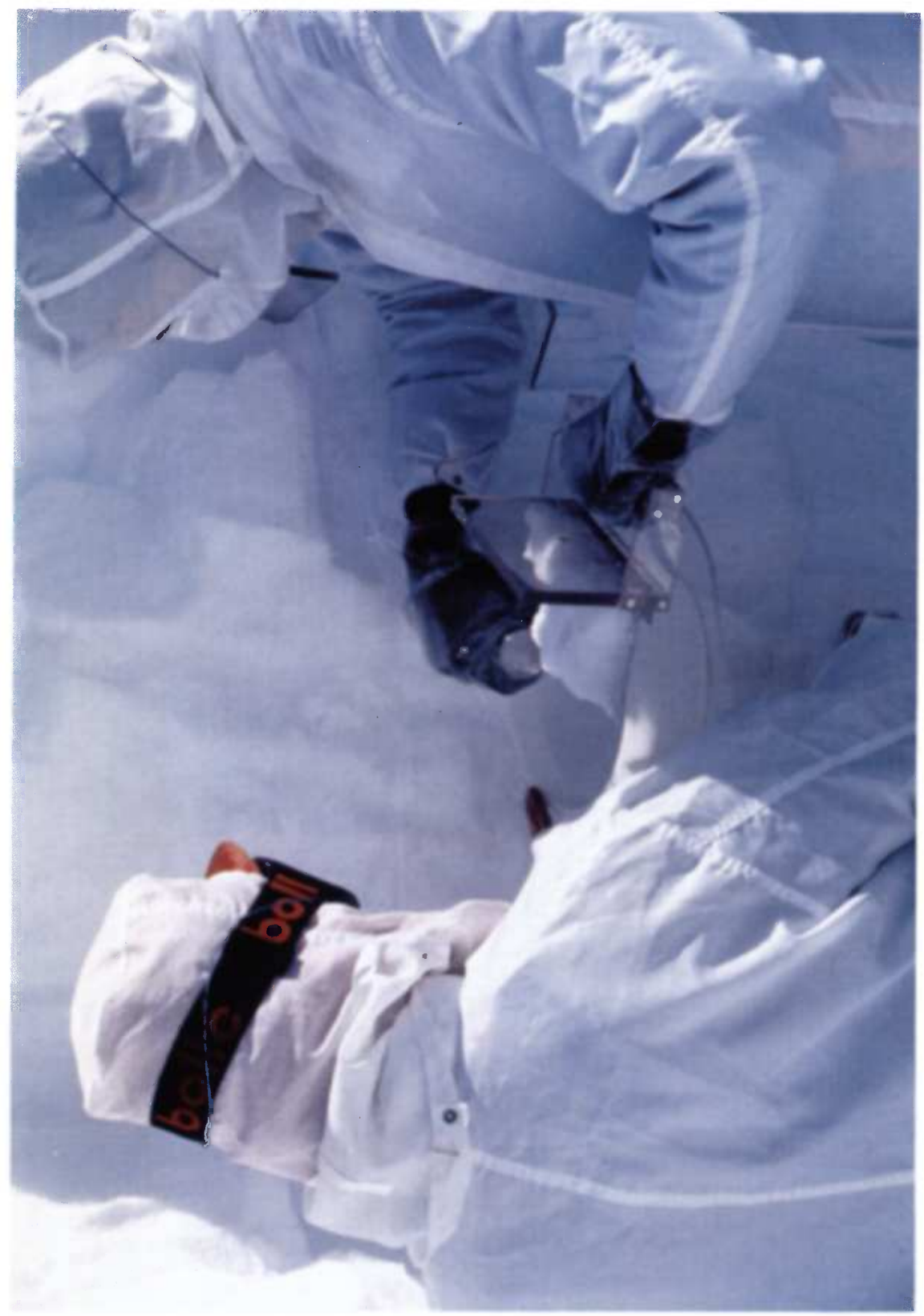

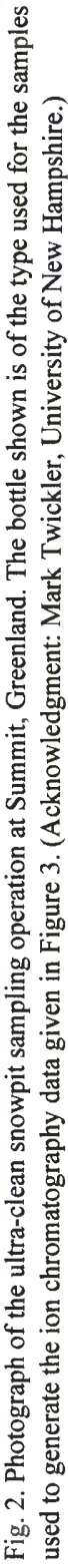

